\title{
Transactions
}

Cite this: Dalton Trans., 2012, 41, 2176

wWW.rsc.org/dalton

PAPER

\section{1,4-Bis(4-nitrosophenyl)piperazine: novel bridging ligand in dinuclear complexes of rhodium(III) and iridium(III) $\dagger$}

\author{
Stefan Wirth, Florian Barth and Ingo-Peter Lorenz* \\ Received 7th September 2011, Accepted 11th November 2011 \\ DOI: $10.1039 / \mathrm{c} 1 \mathrm{dt11696g}$
}

The synthesis, spectroscopic characterization and crystal structures of the first 1,4-bis(4-nitrosophenyl)piperazine (BNPP) (4) bridged dinuclear complexes of rhodium(III) and iridium(III) are presented. The reaction of the $\mu_{2}$-halogenido-bridged dimers $\left[\left(\eta^{5}-\mathrm{C}_{5} \mathrm{Me}_{5}\right) \operatorname{Ir} \mathrm{X}_{2}\right]_{2}[\mathrm{X}=\mathrm{Cl}(\mathbf{5 a}), \mathrm{Br}(\mathbf{5 b}), \mathrm{I}(\mathbf{5} \mathbf{c})]$ and $\left[\left(\eta^{5}-\right.\right.$ $\left.\left.\mathrm{C}_{5} \mathrm{Me}_{5}\right) \mathrm{RhCl}_{2}\right]_{2}(\mathbf{6 a})$ with 4 yields the dinuclear complexes $\left[\left(\eta^{5}-\mathrm{C}_{5} \mathrm{Me}_{5}\right) \operatorname{IrX}_{2}\right]_{2}-\mathrm{BNPP}(\mathbf{7 a}-\mathbf{c})$ and $\left[\left(\eta^{5}-\mathrm{C}_{5} \mathrm{Me}_{5}\right) \mathrm{RhCl}_{2}\right]_{2}-\mathrm{BNPP}(\mathbf{8 a})$. All new compounds were characterized by their NMR, IR and mass spectra. The X-ray structure analyses of the obtained half-sandwich complexes revealed a slightly distorted pseudo-octahedral configuration ("three-legged pianostool") for the metal(III) centers. The bridging BNPP ligand is $\sigma-N$ coordinated by both nitroso groups and shows different conformations of the piperazine ring depending on the solvent used for crystallization. Moreover the crystal structures of 1,4-bis(4-nitrosophenyl)piperazine (4) and its precursor 1,4-diphenylpiperazine (3) are reported.

\section{Introduction}

Since the first reports on the synthesis of aliphatic ${ }^{1,2}$ or aromatic ${ }^{3-5}$ $C$-nitroso compounds were published in 1874 a considerable variety of synthetic routes to high-yield preparations of $C$-nitroso compounds have been developed. ${ }^{6,7}$ Comprehensive reviews are also available for their rich coordination chemistry, ${ }^{\mathbf{8}, 9}$ their biological activities, ${ }^{10}$ possible applications in organic synthesis ${ }^{11}$ or the historical development ${ }^{12}$ of this compound class.

This article is concerned with 1,4-bis(4-nitrosophenyl)piperazine (BNPP) (4), an example of a distinct family of molecules in which two $C$-nitroso groups are to be found not interacting with each other neither intra- nor intermolecularly. Although the first report on 4 is dated to $1879^{13}$ and an improved synthesis of its hydrochloride has existed since $1918^{14}$ only few references about BNPP are available. Most deal with organic molecules like piperazine, ${ }^{14}$ its derivatives ${ }^{15}$ or ${ }^{14} \mathrm{C}$-labelled related compounds ${ }^{16-19}$ where the hydrochloride of $\mathbf{4}$ appears as an intermediate in their synthesis. Some applications in polymer chemistry ${ }^{20-23}$ or as a fungicide ${ }^{24}$ are also known. The only complex containing 4 was published 1994. ${ }^{25}$ Cameron et al. anticipated the possibility of a coordinative polymerization at Sn-centers. This, however, did not occur as proved by several spectroscopic techniques; coordination to the applied tin complex took place with only one of the two $C$-nitroso groups. Until today, this was the only other attempt to use BNPP in coordination chemistry.

Department of Chemistry, Ludwig-Maximilian-University Munich, Butenandtstraße 5-13 (House D), D-81377, Munich, Germany.E-mail:ipl@cup. uni-muenchen.de; Fax: +49-(0)89-2180-77867

$\dagger$ Electronic supplementary information (ESI) available: CCDC reference numbers 838208-838214. For ESI and crystallographic data in CIF or other electronic format see DOI: $10.1039 / \mathrm{c} 1 \mathrm{dt} 11696 \mathrm{~g}$
There are only few metal complexes containing two $\sigma-N$ coordinated $C$-nitroso groups and all of them are stabilized by a chelate system in some way. Vicinal dinitroso compounds $\sigma$ $N$ coordinated to the same metal atom via both NO functions are especially known for cobalt because of their application in organic synthesis, ${ }^{26-37}$ but some examples with ruthenium ${ }^{38,39}$ or platinum $^{40}$ also exist. If the second $C$-NO unit is located not close enough other functional neighbors, ${ }^{9}$ for example a deprotonated amino group, ${ }^{41,42}$ are able to stabilize the chelate as well. In this context it should be mentioned that the presence of two $C$-nitroso and additional functional neighbors does not guarantee $\sigma-N$ coordination or interaction at both possible positions as shown by the different results published for 2,4-dinitrosoresorcinol, unfortunately without crystallographic data. ${ }^{43-47}$

In our attempts dimeric halogenido bridged half-sandwich complexes of $\operatorname{Ir}(\mathrm{III})(\mathbf{5 a}-\mathbf{c})$ and $\mathrm{Rh}$ (III) (6a) were employed because these compounds are easily accessible and remarkably robust; they show good solubility in standard organic solvents and their organic $\pi$-ligand which is relatively inert towards substitution reactions can be used to fine-tune their chemical properties. These are also the reasons why organometallic half-sandwich complexes have been already extensively examined and reviewed as building blocks in supramolecular chemistry during the last decade. ${ }^{4-52}$ Since the first approaches for cubic compounds in the late $1990 \mathrm{~s}^{53,54}$ many polynuclear complexes with different twoand three-dimensional geometries were synthesized using various ligands with N-, O-, S-, P- or NC-donor groups. Recently also $\mathrm{M}-\mathrm{C}$ bonding via $\mathrm{C}-\mathrm{H}$ activation was added to the toolbox for the design of organometallic macrocycles ${ }^{55-59}$ and cages $^{60}$ which can lead to an increased structural stability compared to $\mathrm{M}-\mathrm{O}$ or $\mathrm{M}-\mathrm{N}$ bonds. However, until now $C$-nitroso compounds were not applied as linking or bridging molecules in this field of research. 
In the following, the synthesis, spectroscopic characterization and crystal structures of the first 1,4-bis(4nitrosophenyl)piperazine (4) bridged dinuclear complexes are described. To the best of our knowledge these compounds presented here are the first ones with two not interacting $C$-nitroso groups which coordinate in the $\sigma-N$ mode without any chelate assistance to two different metal centers.

\section{Results and discussion}

\section{Synthesis and characterization of BNPP (4)}

The synthesis of $\mathbf{4}$ is derived from a literature method. ${ }^{14}$ The precursor 1,4-diphenylpiperazine (3) is obtained by condensation from aniline (1) and 1,2-dibromoethane (2) which are heated with sodium carbonate to $130{ }^{\circ} \mathrm{C}$ (Scheme 1). For nitrosation 3 was powdered and suspended in conc. $\mathrm{HCl}$ at $0{ }^{\circ} \mathrm{C}$ and a solution of $\mathrm{NaNO}_{2}$ was added. BNPP (4) precipitated as a green hydrochloride $(\times 2 \mathrm{HCl})$ which was filtered off. The modifications carried out to this method ${ }^{14}$ are described in the experimental section. To get pure 4 its hydrochloride was dissolved in methanol and triethylamine was added to remove $\mathrm{HCl}$ before column chromatography on silica gel. This synthesis yielded $\mathbf{4}$ as air stable, green crystals, soluble for example in dichloromethane or acetone and nearly insoluble in $n$-pentane.

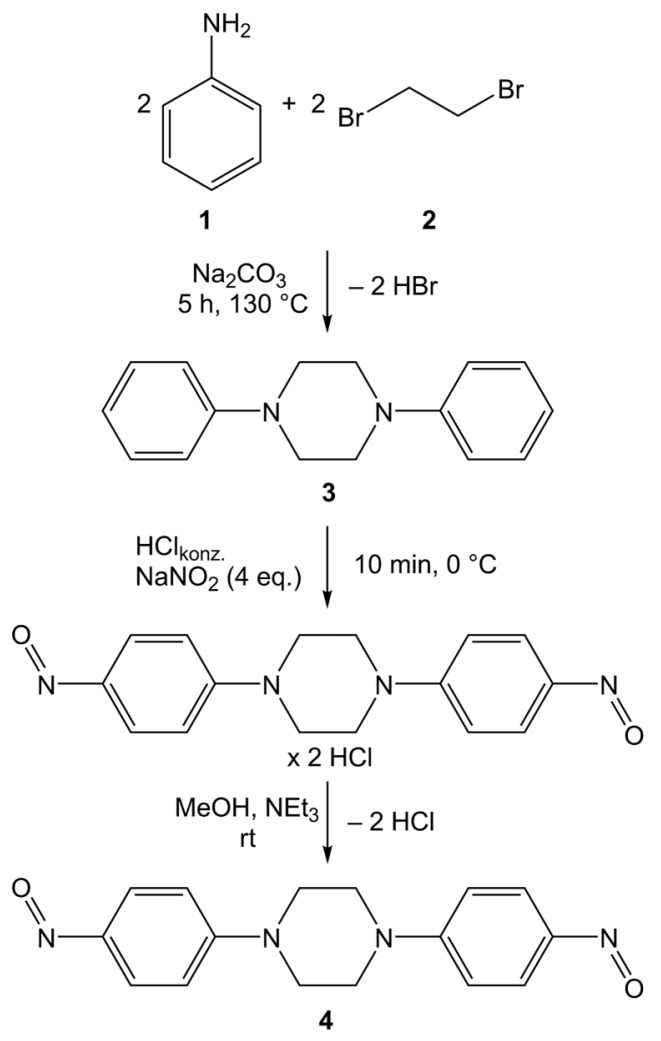

Scheme 1 Synthesis of 1,4-bis(4-nitrosophenyl)piperazine (4) ${ }^{14}$

In contrast to 3 the analytical data available for $\mathbf{4}$ is fragmentary. Therefore BNPP (4) was characterized by ${ }^{1} \mathrm{H}$ and ${ }^{13} \mathrm{C}$ NMR, IR and mass spectra. In the ${ }^{1} \mathrm{H}$ NMR spectra at room temperature a broad signal at $\delta=7.77 \mathrm{ppm}$ is assigned to the protons in the ortho-position of the NO-group. The broadening is caused by the rotation of the nitroso group along the $\mathrm{C}-\mathrm{N}$ bond and its large magnetic anisotropy. "Freezing" this rotation at $-60{ }^{\circ} \mathrm{C}$ leads to a significant splitting of the broad signal ( $\delta=6.94$ and $9.00 \mathrm{ppm})$ whereas that at $9.00 \mathrm{ppm}$ is ascribed to the proton in the "anti position" of the nitroso-O caused by the strong deshielding effect of this functional group. ${ }^{25,61}$ The ${ }^{13} \mathrm{C}$ NMR spectra of $\mathbf{4}$ show the same effect. In solution only at $-60^{\circ} \mathrm{C}$ is the full set of signals detectable. The signal splitting for the carbon atoms in the ortho position of the nitroso group is enhanced to $\Delta=31.1 \mathrm{ppm}(\delta=$ 110.0 and $141.1 \mathrm{ppm}){ }^{61}$ All other protons and carbon atoms are detected in solution in the expected areas. The solid state ${ }^{13} \mathrm{C}$ NMR spectrum of $\mathbf{4}$ is comparable to the low temperature spectrum in solution in the signal position and count. The significant areas of the different NMR spectra in solution and in the solid state are depicted in Fig. 1.

The IR spectra of 4 (KBr pellets) show weak $v(\mathrm{C}-\mathrm{H})$ absorptions between 3100 and $2850 \mathrm{~cm}^{-1}$. At wavenumbers smaller than $1597 \mathrm{~cm}^{-1}$ the fingerprint of 4 is observed. The $v(\mathrm{~N}=\mathrm{O})$ absorption at $1358 \mathrm{~cm}^{-1}$ was located by comparison with the IR spectra of $N, N$-dimethyl-4-nitrosoaniline $\left(v(\mathrm{~N}=\mathrm{O}) 1363 \mathrm{~cm}^{-1}\right)^{9,62}$ whose structure and IR spectra are very similar to 4 . Mass spectrometric investigation in the DEI mode shows the expected $\left[\mathrm{M}^{+}\right]$peak with its characteristic isotope pattern and an assignable fragmentation pattern for compound 4.

Since no crystallographic data were available, the molecular structures of $\mathbf{3}$ and $\mathbf{4}$ were determined using single crystal Xray diffraction. Isothermic diffusion of $n$-pentane into a solution of $\mathbf{3}$ or $\mathbf{4}$ in acetone resulted in the formation of X-ray quality single crystals. The molecular structures with atom numbering are illustrated in Fig. 2 and 3, selected bond lengths and angles are listed in Table 1. Details of the crystallographic data and refinement are summarized in Table 3 .

The piperazine ring in $\mathbf{3}$ shows chair conformation and an inversion center, so both phenyl rings exhibit identical geometry. $\mathrm{C}-\mathrm{N}$ bond lengths lie within the expected range for single bonds while the N1-C1 bond to the aromatic ring is slightly shorter than the $\mathrm{N} 1-\mathrm{C} 7$ and $\mathrm{N} 1-\mathrm{C} 8$ within the piperazine ring. The $\mathrm{sp}^{3}$ hybridization of $\mathrm{N} 1$ is confirmed by angles around $109^{\circ}$ enclosed by $\mathrm{N} 1$ and its neighboring carbon atoms $\mathrm{C} 1, \mathrm{C} 7$ and $\mathrm{C} 8^{i}$ (Table 1 ). $\mathrm{C}-\mathrm{C}$ bond lengths in the phenyl ring range from 1.371(3) to 1.395(2) $\AA$ and prove their aromatic character. The parallel planes of theses aromatic rings show an intramolecular vertical plane-toplane distance of $0.558 \AA$.

Crystallographic characterization of $\mathbf{4}$ exhibits two molecules with different conformations of the piperazine ring (chair and boat/Fig. 3) within the unit cell. 4 in chair conformation possesses an inversion center with similar bonding situations in both aromatic rings (Table 1), as already discussed for 3 . The $\mathrm{N}=\mathrm{O}$ bond length is consistent with the expectation for an aromatic $C$-nitroso compound (1.13-1.29 $\AA)^{9}$ but is a little bit longer than that found for $N, N$-dimethyl-4-nitrosoaniline (1.131 and 1.212 A). ${ }^{63}$ The nitroso group is located in the plane of the aromatic ring (deviation $0.2^{\circ}$ ). N6-C20 and N5-C17 are a little bit shorter than expected for single bonds and indicate a quinoid contribution to the $\mathrm{C} 17-\mathrm{C} 22$ ring. This is supported by shortened $\mathrm{C} 18-\mathrm{C} 19$ and $\mathrm{C} 21-\mathrm{C} 22$ bonds in comparison to 3 or to the other $\mathrm{C}-\mathrm{C}$ bond lengths in the ring. $\mathrm{C}-\mathrm{N}$ and $\mathrm{C}-\mathrm{C}$ bonds in the piperazine unit are single bonds without any doubt. Nitrosation of $\mathbf{3}$ also effects the geometry of the piperazine- $\mathrm{N}$ which is noticeable flattened in 
A
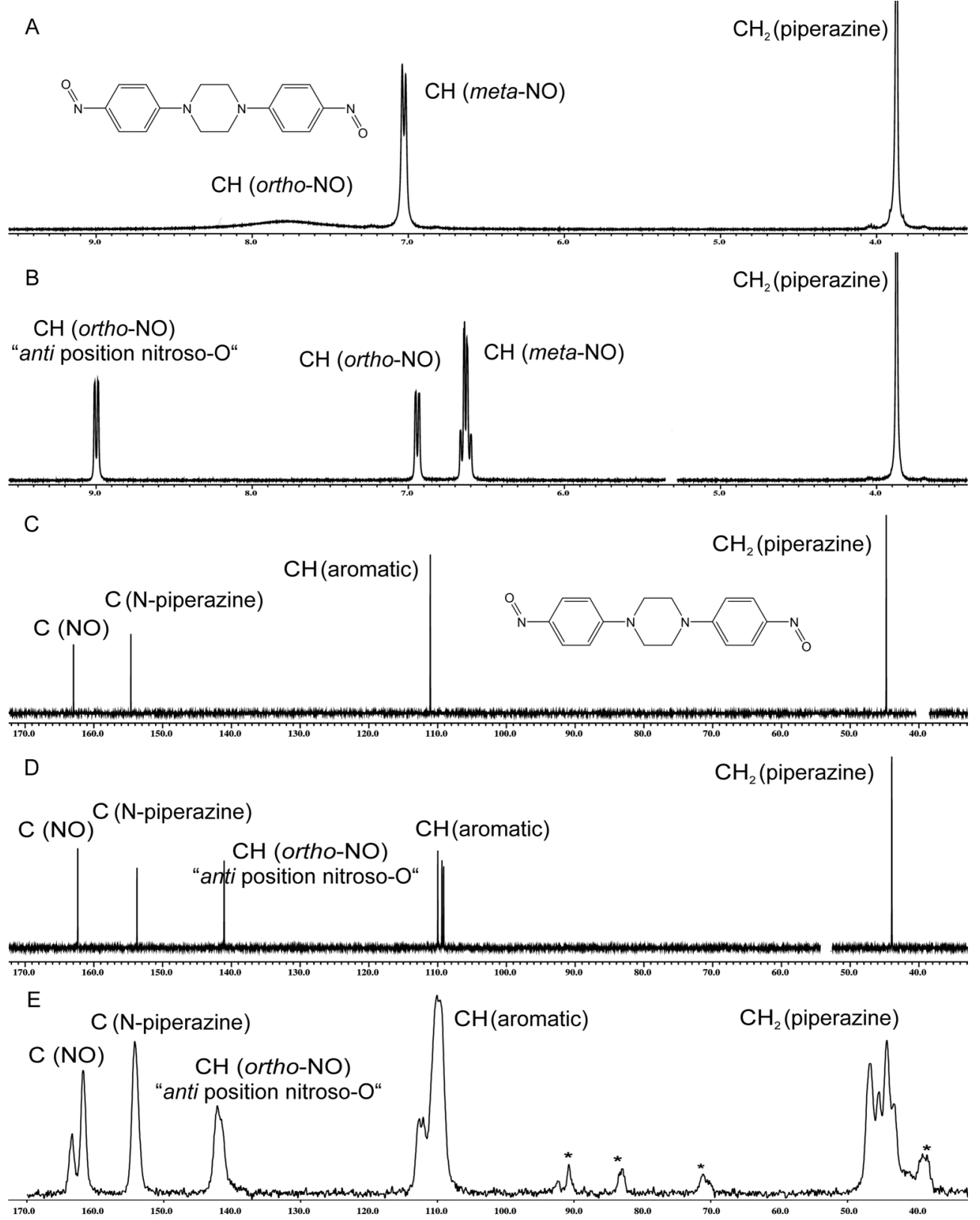

Fig. 1 Significant areas of the ${ }^{1} \mathrm{H}$ NMR $\left(\mathrm{A}:\left(\mathrm{CD}_{3}\right)_{2} \mathrm{SO}, \mathrm{B}: \mathrm{CDCl}_{2}\right)$ and the ${ }^{13} \mathrm{C} \mathrm{NMR}$ spectra $\left(\mathrm{C}:\left(\mathrm{CD}_{3}\right)_{2} \mathrm{SO}, \mathrm{D}\right.$ : $\mathrm{CDCl} \mathrm{C}_{2}$, E: solid state) of 4 at room temperature (A, C, E) and at $-60{ }^{\circ} \mathrm{C}(\mathrm{B}, \mathrm{D})$ (solvent signals are omitted for clarity: $\mathrm{B}: 5.32 \mathrm{ppm}\left(\mathrm{CDCl}_{2}\right) ; \mathrm{C}: 39.5 \mathrm{ppm}\left((\mathrm{CD})_{2} \mathrm{SO}\right)$; $\mathrm{D}: 53.5 \mathrm{ppm}(\mathrm{CDCl})_{2}$; spinning sidebands at $\mathrm{E}$ are marked with $\left.{ }^{*}\right)$.

4. That becomes evident by the sum of angles which is increased from $342.8^{\circ}$ for $\mathrm{N} 1$ in $\mathbf{3}$ to $353.8^{\circ}$ for $\mathrm{N} 5$ in $\mathbf{4}$. This flattening also explains the decline of the intramolecular vertical plane-to-plane distance of the parallel phenyl rings to only $0.287 \AA$.

The most obvious differences between the two molecular units of $\mathbf{4}$ is the orientation of the phenyl rings which are not parallel in the boat conformation but enclose an angle of $56.27^{\circ}$. By lack of an inversion center within the piperazine ring both sides vary a little in their bonding situation (Table 1 ). $\mathrm{N}=\mathrm{O}$ bond lengths lie in the same range as in the chair conformation whereas the deviation of the nitroso groups out of the phenyl planes is slightly increased. Surprisingly in the boat conformation three of the four $\mathrm{C}-\mathrm{N}$ bonds to the aromatic rings $(\mathrm{N} 1-\mathrm{C} 1, \mathrm{~N} 2-\mathrm{C} 11$, $\mathrm{N} 4-\mathrm{C} 14)$ are distinctly shorter than in the chair conformation. Shorter bond lengths at these positions suggest a higher quinoid contribution to the aromatic system for this conformation. (Fig. 3)

This is as well indicated by an almost planar geometry of the piperazine nitrogen atoms (sum of angles N1 359.7 , N2 360.0 $0^{\circ}$ ). All other $\mathrm{C}-\mathrm{N}$ and $\mathrm{C}-\mathrm{C}$ bonds within the heterocycle are in the expected range for single bonds and are comparable to those of $\mathbf{3}$ (Table 1). 
Table 1 Selected bond lengths $[\AA]$ and angles $\left[{ }^{\circ}\right]$ of compounds 3 and 4

\begin{tabular}{|c|c|c|c|c|c|c|c|c|c|}
\hline \multicolumn{4}{|c|}{ Bond lengths $[\AA ̊]$} & \multicolumn{4}{|l|}{ Angles $\left[{ }^{\circ}\right]$} & \multicolumn{2}{|l|}{ Torsion angles $\left[{ }^{\circ}\right]$} \\
\hline \multicolumn{10}{|c|}{3 (Chair conformation) } \\
\hline $\mathrm{N} 1-\mathrm{C} 1$ & $1.412(2)$ & $\mathrm{C} 2-\mathrm{C} 3$ & $1.375(2)$ & $\mathrm{C} 1-\mathrm{N} 1-\mathrm{C} 7$ & $117.0(2)$ & $\mathrm{C} 2-\mathrm{C} 1-\mathrm{N} 1$ & $119.8(2)$ & $\mathrm{C} 7-\mathrm{N} 1-\mathrm{C} 1-\mathrm{C} 6$ & $1.6(2)$ \\
\hline $\mathrm{N} 1-\mathrm{C} 7$ & $1.459(2)$ & $\mathrm{C} 5-\mathrm{C} 6$ & $1.386(2)$ & $\mathrm{C} 1-\mathrm{N} 1-\mathrm{C} 8 \# 1$ & $115.6(2)$ & $\mathrm{C} 6-\mathrm{C} 1-\mathrm{N} 1$ & $122.5(2)$ & $\mathrm{C} 8 \# 1-\mathrm{N} 1-\mathrm{C} 1-\mathrm{C} 2$ & $-48.1(2)$ \\
\hline $\mathrm{N} 1-\mathrm{C} 8 \# 1$ & $1.46(3)$ & $\mathrm{C} 7-\mathrm{C} 8$ & $1.507(2)$ & $\mathrm{C} 7-\mathrm{N} 1-\mathrm{C} 8 \# 1$ & $110.2(2)$ & & & $\mathrm{N} 1-\mathrm{C} 7-\mathrm{C} 8-\mathrm{N} 1 \# 1$ & $-56.9(2)$ \\
\hline \multicolumn{10}{|c|}{4 (Chair conformation) } \\
\hline O3-N6 & $1.245(2)$ & N5-C23 & $1.463(2)$ & O3-N6-C20 & $116.7(2)$ & $\mathrm{C} 17-\mathrm{N} 5-\mathrm{C} 24$ & $120.8(2)$ & O3-N6-C20-C19 & $-0.2(3)$ \\
\hline N6-C20 & $1.395(2)$ & $\mathrm{C} 23-\mathrm{C} 24 \# 2$ & $1.492(3)$ & $\mathrm{C} 19-\mathrm{C} 20-\mathrm{N} 6$ & $125.2(2)$ & $\mathrm{C} 24-\mathrm{N} 5-\mathrm{C} 23$ & $111.9(2)$ & $\mathrm{C} 23-\mathrm{N} 5-\mathrm{C} 17-\mathrm{C} 22$ & $29.0(3)$ \\
\hline N5-C17 & $1.376(2)$ & C18-C19 & $1.364(2)$ & $\mathrm{C} 21-\mathrm{C} 20-\mathrm{N} 6$ & $116.2(2)$ & N5-C23-C24\#2 & $113.1(2)$ & C24-N5-C17-C18 & $-3.2(3)$ \\
\hline N5-C24 & $1.460(2)$ & $\mathrm{C} 21-\mathrm{C} 22$ & $1.369(2)$ & C17-N5-C23 & $121.1(2)$ & N5-C24-C23\#2 & $112.4(2)$ & N5-C23-C24-N5\#2 & $52.2(2)$ \\
\hline \multicolumn{10}{|c|}{4 (Boat conformation) } \\
\hline $\mathrm{O} 1-\mathrm{N} 3$ & $1.241(2)$ & $\mathrm{O} 2-\mathrm{N} 4$ & $1.254(2)$ & $\mathrm{O} 1-\mathrm{N} 3-\mathrm{C} 4$ & $115.7(2)$ & $\mathrm{O} 2-\mathrm{N} 4-\mathrm{C} 14$ & $115.9(2)$ & $\mathrm{O} 1-\mathrm{N} 3-\mathrm{C} 4-\mathrm{C} 3$ & $-2.9(3)$ \\
\hline N3-C4 & $1.412(2)$ & $\mathrm{N} 4-\mathrm{C} 14$ & $1.389(2)$ & $\mathrm{C} 3-\mathrm{C} 4-\mathrm{N} 3$ & $124.5(2)$ & $\mathrm{C} 13-\mathrm{C} 14-\mathrm{N} 4$ & $125.4(2)$ & C7-N1-C1-C6 & $-8.2(3)$ \\
\hline $\mathrm{N} 1-\mathrm{C} 1$ & $1.363(2)$ & $\mathrm{N} 2-\mathrm{C} 11$ & $1.350(2)$ & $\mathrm{C} 5-\mathrm{C} 4-\mathrm{N} 3$ & $116.2(2)$ & $\mathrm{C} 15-\mathrm{C} 14-\mathrm{N} 4$ & $115.9(2)$ & $\mathrm{C} 10-\mathrm{N} 1-\mathrm{C} 1-\mathrm{C} 2$ & $-14.6(3)$ \\
\hline $\mathrm{N} 1-\mathrm{C} 10$ & $1.456(2)$ & N2-C8 & $1.461(2)$ & $\mathrm{C} 1-\mathrm{N} 1-\mathrm{C} 7$ & $120.9(2)$ & $\mathrm{C} 11-\mathrm{N} 2-\mathrm{C} 9$ & $121.6(2)$ & N1-C7-C8-N2 & $-59.4(2)$ \\
\hline N1-C7 & $1.463(2)$ & N2-C9 & $1.471(2)$ & $\mathrm{C} 1-\mathrm{N} 1-\mathrm{C} 10$ & $123.1(2)$ & $\mathrm{C} 11-\mathrm{N} 2-\mathrm{C} 8$ & $123.2(2)$ & $\mathrm{O} 2-\mathrm{N} 4-\mathrm{C} 14-\mathrm{C} 13$ & $3.8(3)$ \\
\hline $\mathrm{C} 7-\mathrm{C} 8$ & $1.513(3)$ & C9-C10 & $1.516(2)$ & $\mathrm{C} 10-\mathrm{N} 1-\mathrm{C} 7$ & $115.7(2)$ & C8-N2-C9 & $115.2(2)$ & $\mathrm{C} 8-\mathrm{N} 2-\mathrm{C} 11-\mathrm{C} 12$ & $-8.7(3)$ \\
\hline $\mathrm{C} 2-\mathrm{C} 3$ & $1.364(2)$ & $\mathrm{C} 12-\mathrm{C} 13$ & $1.362(2)$ & N1-C7-C8 & $110.7(2)$ & $\mathrm{N} 2-\mathrm{C} 8-\mathrm{C} 7$ & $110.9(2)$ & $\mathrm{C} 9-\mathrm{N} 2-\mathrm{C} 11-\mathrm{C} 16$ & $-6.4(3)$ \\
\hline $\mathrm{C} 5-\mathrm{C} 6$ & $1.371(2)$ & $\mathrm{C} 15-\mathrm{C} 16$ & $1.360(2)$ & $\mathrm{N} 1-\mathrm{C} 10-\mathrm{C} 9$ & $111.0(2)$ & $\mathrm{N} 2-\mathrm{C} 9-\mathrm{C} 10$ & $110.8(2)$ & N2-C9-C10-N1 & $-58.4(2)$ \\
\hline
\end{tabular}

Symmetry transformations used to generate equivalent atoms: $\# 1-x+1,-y,-z+1 ; \# 2-x+2,-y+1,-z+1$

Table 2 Selected bond lengths $[\AA]$ and angles $\left[{ }^{\circ}\right]$ of $\mathbf{7 a}-\mathbf{c}$ and $\mathbf{8 a}$ compared to equivalent data of $\mathbf{4}$

\begin{tabular}{|c|c|c|c|c|c|c|c|c|c|c|}
\hline & \multicolumn{10}{|c|}{ Bond lengths [Å] } \\
\hline & $\mathrm{M}-\mathrm{X} 1$ & $\mathrm{M}-\mathrm{X} 2$ & $\mathrm{M}-\mathrm{N}(\mathrm{O})$ & $\mathrm{N}-\mathrm{O}$ & $\mathrm{N}(\mathrm{O})-\mathrm{C}$ & $\mathrm{N} 1-\mathrm{C} 1$ & $\mathrm{~N} 1-\mathrm{C} 7$ & $\mathrm{~N} 1-\mathrm{C} 8$ & $\mathrm{C} 2-\mathrm{C} 3$ & $\mathrm{C} 5-\mathrm{C} 6$ \\
\hline 4 (Chair) $^{b}$ & - & - & - & $1.245(2)$ & $1.395(2)$ & $1.376(2)$ & $1.463(2)$ & $1.460(2)$ & $1.364(2)$ & $1.369(2)$ \\
\hline \multirow[t]{2}{*}{4 (Boat) $^{b}$} & - & - & - & $1.241(2)$ & $1.412(2)$ & $1.363(2)$ & $1.463(2)$ & $1.456(2)$ & $1.364(2)$ & $1.371(2)$ \\
\hline & - & - & - & $1.254(2)$ & $1.389(2)$ & $1.350(2)$ & $1.471(2)$ & $1.461(2)$ & $1.362(2)$ & $1.360(2)$ \\
\hline 7a (Chair) & $2.388(2)$ & $2.420(2)$ & $2.069(3)$ & $1.245(4)$ & $1.397(5)$ & $1.360(5)$ & $1.458(6)$ & $1.461(5)$ & $1.345(6)$ & $1.363(6)$ \\
\hline \multirow[t]{2}{*}{$7 \mathbf{a}^{\prime}(\text { Boat })^{a, b}$} & $2.399(2)$ & $2.414(2)$ & $2.061(7)$ & $1.256(9)$ & $1.39(2)$ & $1.35(2)$ & $1.47(2)$ & $1.49(2)$ & $1.37(2)$ & $1.37(2)$ \\
\hline & $2.419(2)$ & $2.407(2)$ & $2.088(8)$ & $1.270(9)$ & $1.38(2)$ & $1.34(2)$ & $1.49(2)$ & $1.47(2)$ & $1.35(2)$ & $1.37(2)$ \\
\hline 7b (Chair) & $2.513(2)$ & $2.538(2)$ & $2.064(7)$ & $1.252(8)$ & $1.432(9)$ & $1.366(9)$ & $1.48(2)$ & $1.454(9)$ & $1.363(9)$ & $1.348(9)$ \\
\hline 7c (Boat) & $2.7132(6)$ & $2.7109(7)$ & $2.072(6)$ & $1.250(7)$ & $1.387(9)$ & $1.351(9)$ & $1.476(9)$ & $1.483(9)$ & $1.35(2)$ & $1.38(2)$ \\
\hline \multirow[t]{3}{*}{ 8a (Chair) } & $2.3950(7)$ & $2.4308(7)$ & $2.097(2)$ & $1.246(3)$ & $1.389(3)$ & $1.355(3)$ & $1.464(4)$ & $1.459(3)$ & $1.352(4)$ & $1.365(4)$ \\
\hline & \multicolumn{6}{|l|}{ Angles $\left[{ }^{\circ}\right]$} & \multicolumn{4}{|c|}{ Torsion angles $\left[{ }^{\circ}\right]$} \\
\hline & $\mathrm{X} 1-\mathrm{M}-\mathrm{X} 2$ & $\mathrm{~N}-\mathrm{M}-\mathrm{X} 1$ & $\mathrm{~N}-\mathrm{M}-\mathrm{X} 2$ & $\mathrm{C} 1-\mathrm{N} 1-\mathrm{C} 7$ & $\mathrm{C} 1-\mathrm{N} 1-\mathrm{C} 8$ & $\mathrm{C} 7-\mathrm{N} 1-\mathrm{C} 8$ & $\mathrm{O} 1-\mathrm{N} 2-\mathrm{C} 4-\mathrm{C} 3$ & $\mathrm{C} 2-\mathrm{C} 1-\mathrm{N} 1-\mathrm{C} 8$ & $\mathrm{C} 6-\mathrm{C} 1-\mathrm{N} 1-\mathrm{C} 7$ & \\
\hline $4{\text { (Chair })^{b}}$ & - & - & - & $121.1(2)$ & $120.8(2)$ & $111.9(2)$ & $-0.2(3)$ & $-3.2(3)$ & $29.0(3)$ & \\
\hline \multirow[t]{2}{*}{4 (Boat) $^{b}$} & - & - & - & $120.9(2)$ & $123.1(2)$ & $115.7(2)$ & $-2.9(3)$ & $-14.6(3)$ & $-8.2(3)$ & \\
\hline & - & - & - & $121.6(2)$ & $123.2(2)$ & $115.2(2)$ & $3.8(3)$ & $-8.7(3)$ & $-6.4(3)$ & \\
\hline 7a (Chair) & $87.12(4)$ & $85.5(2)$ & $93.27(9)$ & $124.0(4)$ & $124.4(4)$ & $110.7(3)$ & $8.1(6)$ & $5.6(7)$ & $-6.8(7)$ & \\
\hline \multirow[t]{2}{*}{$7 \mathbf{a}^{\prime}(\text { Boat })^{a, b}$} & $87.21(9)$ & $88.9(2)$ & $93.2(2)$ & $120.7(7)$ & $123.3(7)$ & $115.1(7)$ & $9(2)$ & $23(2)$ & $9(2)$ & \\
\hline & $87.63(9)$ & $88.2(2)$ & $90.5(2)$ & $121.7(7)$ & $123.2(7)$ & $114.7(7)$ & $-3(2)$ & $15(2)$ & $8(2)$ & \\
\hline $7 \mathbf{b}$ (Chair) & $88.12(4)$ & $84.8(2)$ & $94.5(2)$ & $122.9(7)$ & $124.7(7)$ & $111.5(6)$ & $11(2)$ & $2(2)$ & $-10(2)$ & \\
\hline $7 c$ (Boat) & $89.02(2)$ & $87.7(2)$ & $95.4(2)$ & $123.3(6)$ & $122.2(6)$ & $114.5(6)$ & $3(2)$ & $2(2)$ & $1(2)$ & \\
\hline 8a (Chair) & $89.28(3)$ & $86.47(6)$ & $95.12(6)$ & $124.1(2)$ & $124.6(2)$ & $110.7(2)$ & $7.7(4)$ & $5.8(4)$ & $-5.5(4)$ & \\
\hline
\end{tabular}

${ }^{a}$ If more than one complex molecule in similar conformation was present in the assmyetric unit, only the data for one unit are listed. ${ }^{b}$ Column headings are derived from the metal complexes with inversion center $(\mathbf{7 a}, \mathbf{7 b}, \mathbf{7 c}, \mathbf{8 a})$, for compounds with different atom numbering $\left(\mathbf{4}, \mathbf{7} \mathbf{a}^{\prime}\right)$ comparable bond lengths and angles are given.

\section{Synthesis and characterization of the BNPP bridged complexes $7 \mathbf{a}-\mathbf{c}$ and $8 \mathbf{a}$}

According to Scheme 2 the reaction of BNPP (4) with the starting complexes $\left[\left(\eta^{5}-\mathrm{C}_{5} \mathrm{Me}_{5}\right) \operatorname{IrX}_{2}\right]_{2}[\mathrm{X}=\mathrm{Cl}(\mathbf{5 a}), \mathrm{Br}(\mathbf{5 b}), \mathrm{I}(\mathbf{5} \mathbf{c})]$ or $\left[\left(\eta^{5}-\right.\right.$ $\left.\left.\mathrm{C}_{5} \mathrm{Me}_{5}\right) \mathrm{RhCl}_{2}\right]_{2}$ (6a) was carried out in dry dichloromethane (saturated solutions) at room temperature. The nucleophilic cleavage of the dimers by $\mathbf{4}$ yields the products as green $(\mathbf{7 a}-\mathbf{c})$ or brown (8a) solids which decompose slowly when exposed to moist air. If dissolved in polar solvents such as DMF, DMSO, acetone or dichloromethane the ligand is released and both starting materials are formed back. Since the complexes are insoluble in nonpolar solvents addition of $n$-pentane does not cause this effect.

Due to the described decomposition in unsaturated solution reasonable characterization by NMR spectroscopy was possible only as ${ }^{13} \mathrm{C}$ NMR in the solid state. As an example, two of these spectra (7a and $\mathbf{c}$ ) are depicted with that of 4 in Fig. 4. Surprisingly the spectra differ in the signal count for equivalent atoms at some positions. For example the " $\mathrm{CH}_{2}$ " carbons of the piperazine rings show four peaks for uncoordinated $\mathbf{4}$ whereas only two signals are detected in 7a and just one in 7c (Fig. 4). A different kind and count of conformations in the solid state may be an explanation for this result. Due to the described decompositions in solvents for 


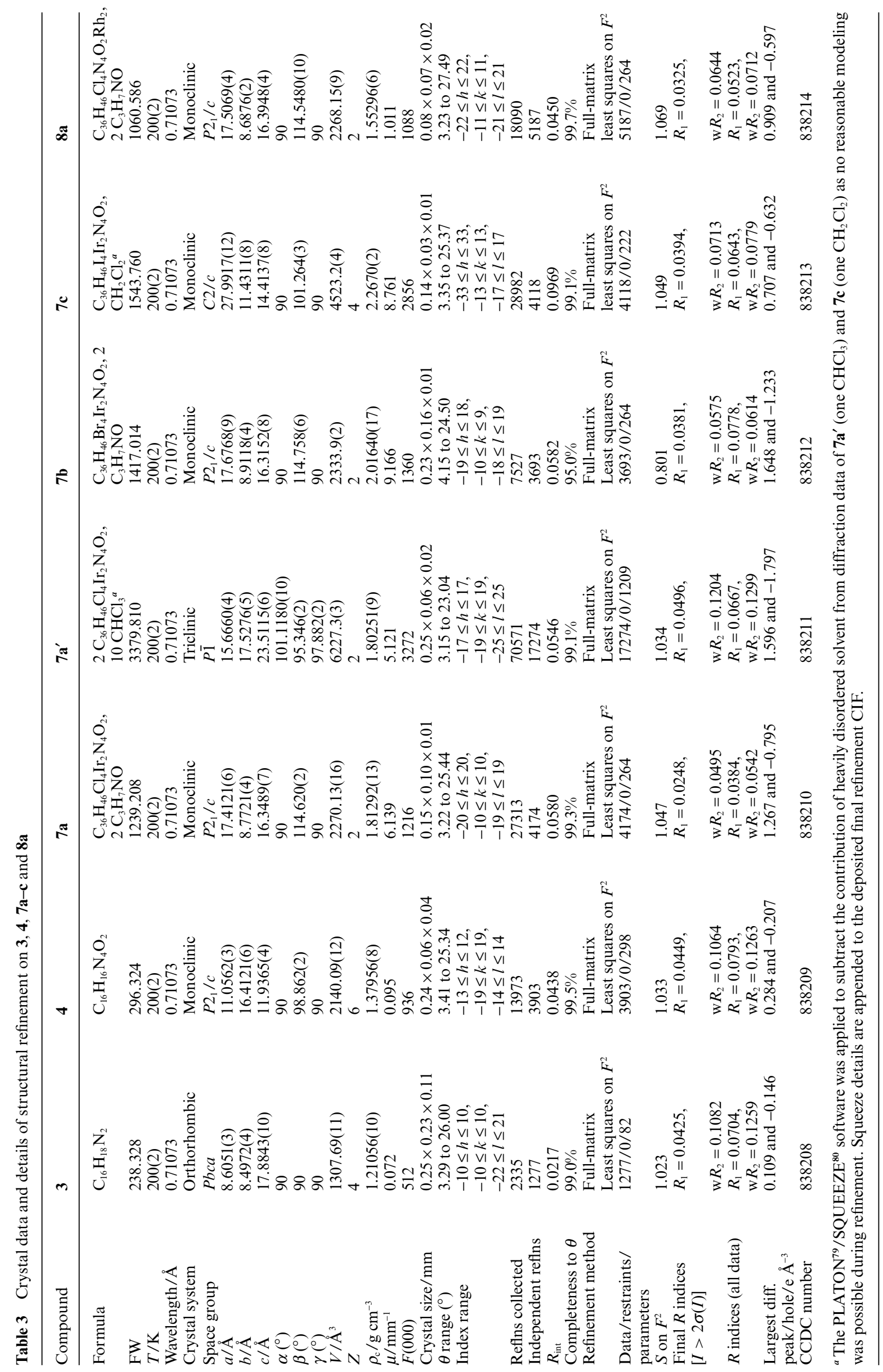



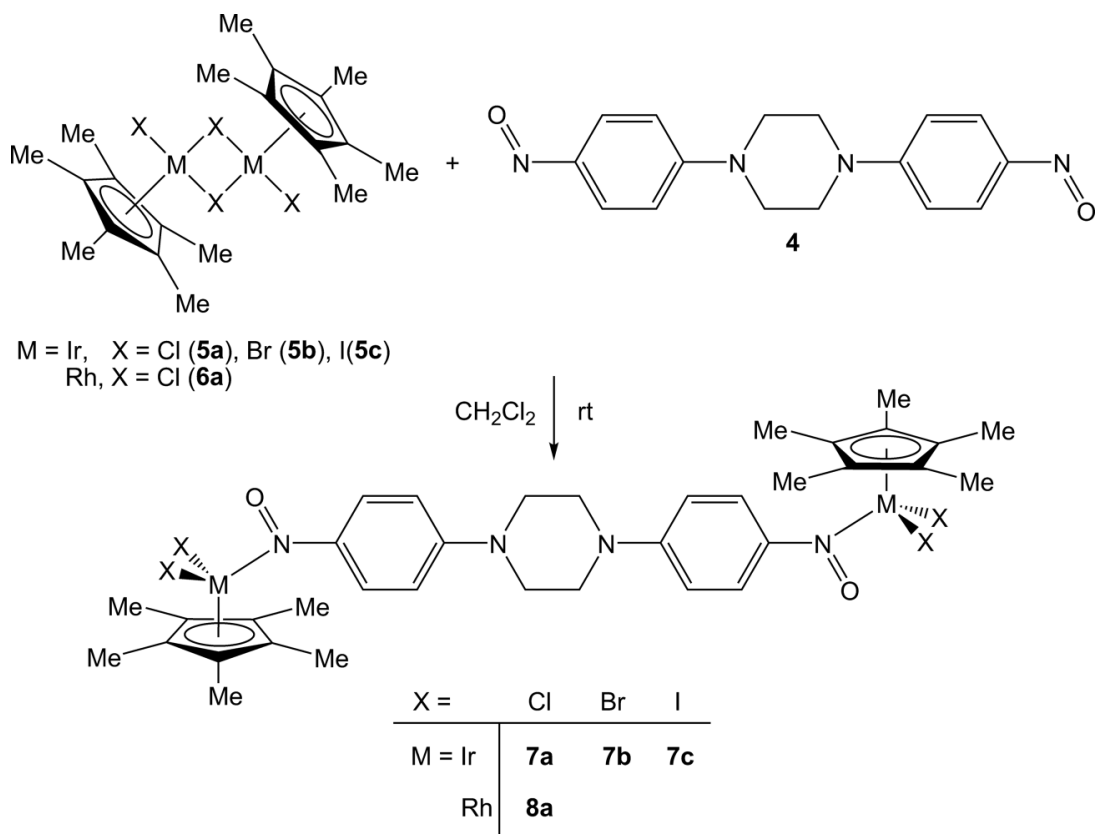

Scheme 2 Synthesis of the iridium(III) (7a-c) and rhodium(III) (8a) complexes with $\mathbf{4}$ as a bridging ligand.

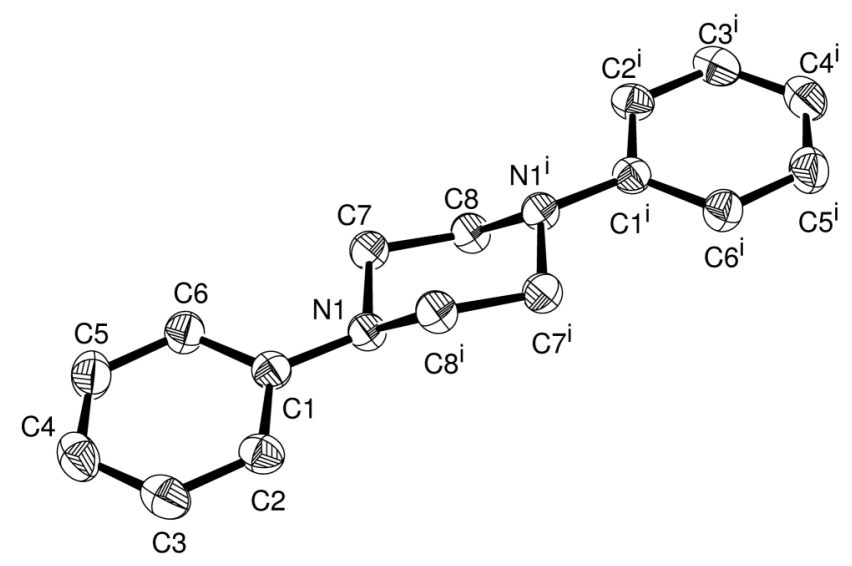

Fig. 2 Molecular structure of 1,4-diphenylpiperazine (3). Hydrogen atoms are omitted for clarity. Displacement ellipsoids are drawn at $30 \%$ probability level.

7a-c and 8a neutralizing this effect by measurement in the liquid state is only feasible for uncoordinated 4 (Fig. 1). A consistent trend for the coordination induced shifts of the signals can only be detected for a few atoms. For example the ortho-carbon atom (anti position nitroso-O) shows after coordination a little shift to a higher field compared to 4 . A detailed comparison of the corresponding signals is available in tabular form as ESI (Table 4). $\dagger$

In the IR spectra of $7 \mathbf{a}-\mathbf{c}$ and $\mathbf{8 a}(\mathrm{KBr}$ pellets) several weak $v(\mathrm{C}-$ $\mathrm{H})$ absorptions are located between 3095 and $2860 \mathrm{~cm}^{-1}$. Within the fingerprint area (wavenumbers smaller than $1597 \mathrm{~cm}^{-1}$ ) $v(\mathrm{~N}=\mathrm{O}$ ) absorptions are observed from 1351 to $1347 \mathrm{~cm}^{-1}$ which are shifted to marginally lower frequencies compared to $4\left(1358 \mathrm{~cm}^{-1}\right)$. This small shift lies in the expected scale for $\sigma-N$ coordination of $C$ nitroso compounds. ${ }^{9,62}$

The mass spectra of $\mathbf{7 a - c}$ in the $\mathrm{FAB}^{+}$mode exhibit the parent peaks as well as comparable fragmentation patterns resulting from the loss of the halogenido ligands only with weak intensity. For such high molecular masses (900 to $1500 \mathrm{~g} \mathrm{~mol}^{-1}$ ) this finding is not astonishing. Despite this low intensity the unique isotope pattern is observed for all peaks up to $\left[\mathrm{M}^{+}\right]$of $7 \mathrm{c}$ at $1459.0 \mathrm{~g}$ $\mathrm{mol}^{-1}$. Complex 8a does not show an $\left[\mathrm{M}^{+}\right]$peak at all, only the characteristic fragmentation and isotope patterns are detected.

Single crystals suitable for X-Ray diffraction analysis were obtained by isothermic diffusion of $n$-pentane into a solution of DMF (7a, 7b, 8a), chloroform $\left(\mathbf{7} \mathbf{a}^{\prime}\right)$ or dichloromethane (7c). Crystallographic data and details of the structure refinements are summarized in Table 3. An interesting side effect of the attempts to gain crystals in good quality under different conditions is the discovery of the solvent dependent conformation of the piperazine ring. If DMF was employed to solve the complexes the chair conformation was always found (7a, 7b, 8a). Use of chloroform (7a') or dichloromethane (7c) leads to a piperazine ring only in the boat conformation. For example the two units with different conformation in the molecular structure obtained for complex 7a, depending on the different solvent used for crystallization (DMF or $\mathrm{CHCl}_{3}$ ), are depicted with atom numbering in Fig. 5. ORTEP ${ }^{64}$ plots of all molecular structures with the closest interacting solvent molecules and the molecular packing within the unit cell are available as ESI. $\dagger$ Only for the crystals grown in DMF direct interaction of the solvent molecules with the piperazine ring via hydrogen bonding is observed. The data for these hydrogen bonds are listed in Table 6 as ESI. $\uparrow$ Selected bond lengths and angles of $7 \mathbf{a}-\mathbf{c}$ and $8 \mathbf{a}$ are listed and compared with those of $\mathbf{4}$ in Table 2.

1,4-Bis(4-nitrosophenyl)piperazine (4) acts in all complexes without any doubt as a bridging ligand between two slightly distorted pseudo-octahedral rhodium(III) or iridium(III) centers, respectively. This is important because for the only other compound containing $\mathbf{4}$ as ligand terminal monocoordination via one $C$-nitroso group to tin was published. ${ }^{25}$ The coordination sphere ("three-legged pianostool" configuration) of each metal consists of one $\eta^{5}$-pentamethylcyclopentadienyl, two terminal halogenido 


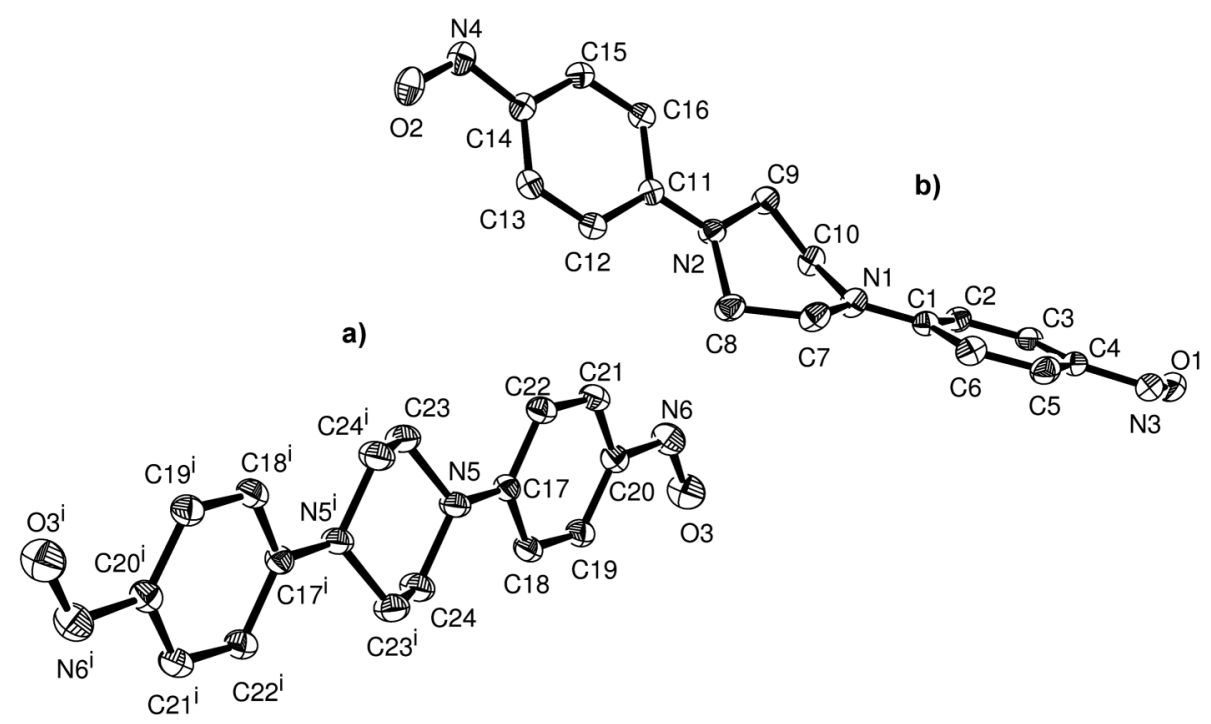

Fig. 3 Molecular structure of 1,4-bis(4-nitrosophenyl)piperazine (4) in its chair (a) and boat (b) conformation. Hydrogen atoms are omitted for clarity. Displacement ellipsoids are drawn at $30 \%$ probability level.

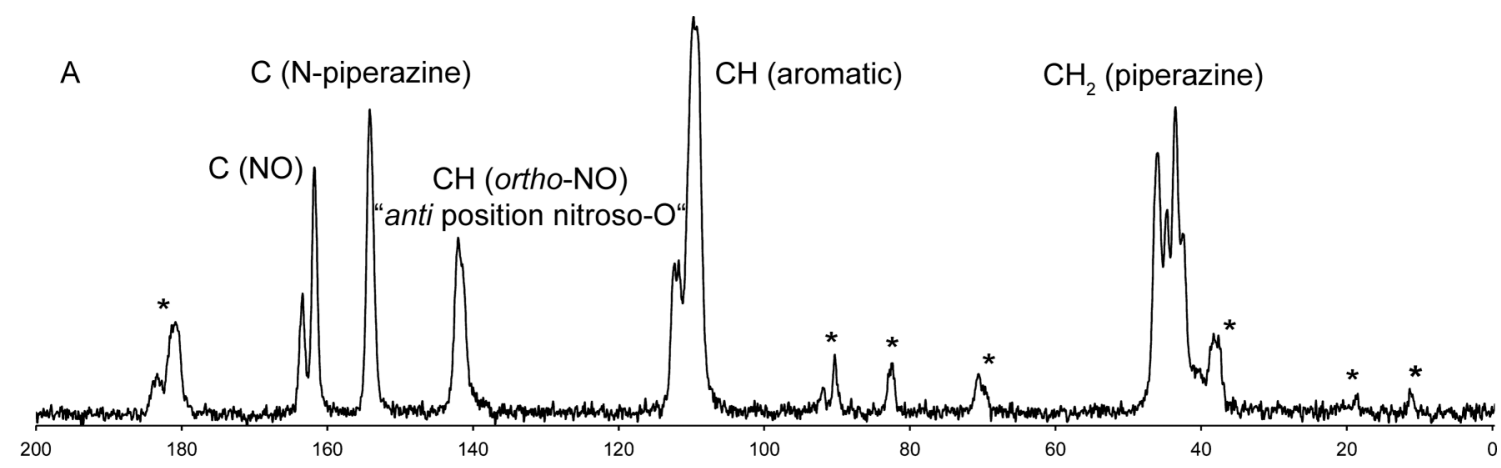

B

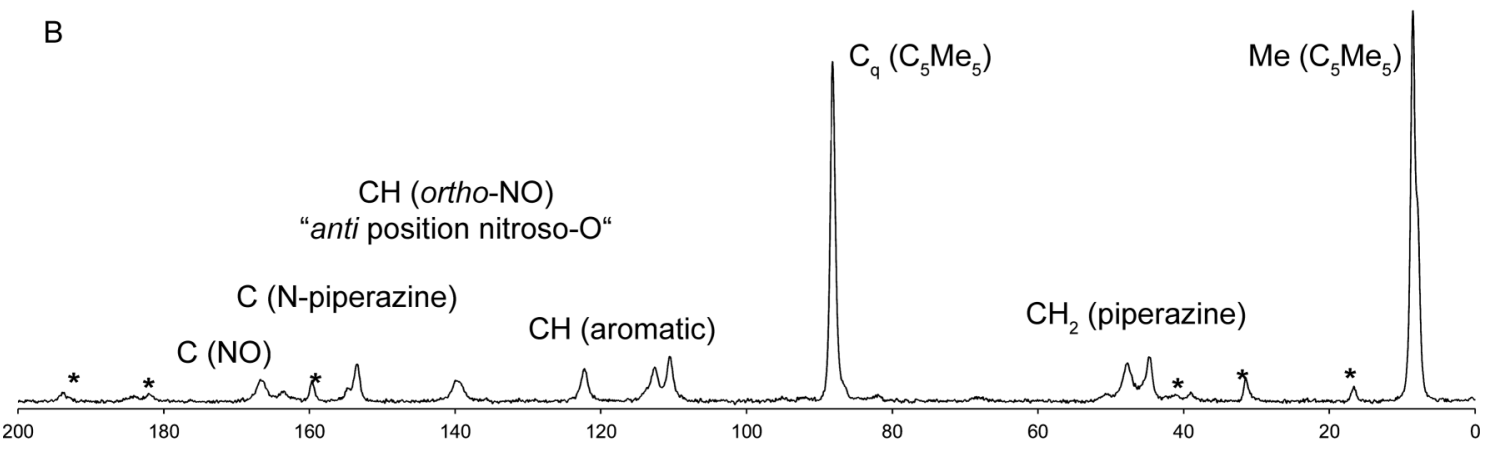

C

$\mathrm{C}_{\mathrm{q}}\left(\mathrm{C}_{5} \mathrm{Me}_{5}\right)$

$\mathrm{Me}\left(\mathrm{C}_{5} \mathrm{Me}_{5}\right)$

$\mathrm{CH}$ (ortho-NO)

"anti position nitroso-O"

$\mathrm{C}$ (N-piperazine)

$$
\mathrm{C}(\mathrm{NO})
$$

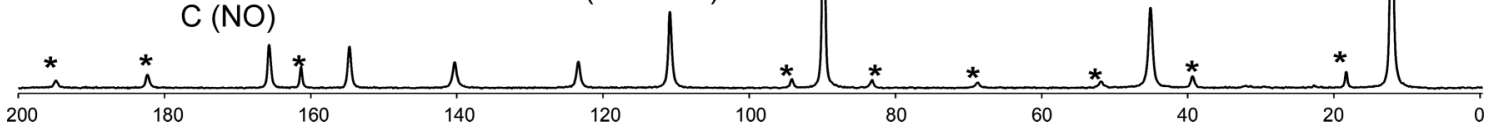

Fig. $4{ }^{13} \mathrm{C}$ NMR solid state spectra of $\mathbf{4}(\mathrm{A}), \mathbf{7 a}(\mathrm{B})$ and $7 \mathbf{c}(\mathrm{C})$ at room temperature (spinning sidebands are marked with *). 

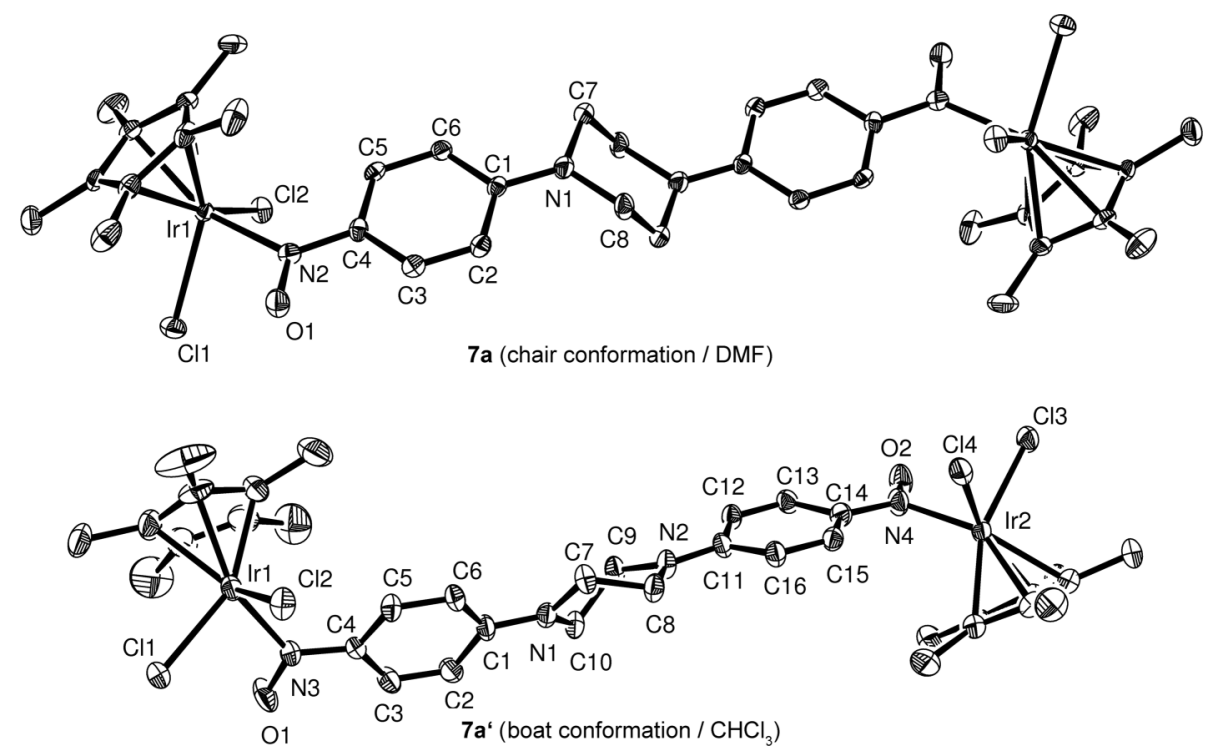

Fig. 5 Molecular structures of $\mathbf{7 a}$ crystallized from DMF (chair conformation/structure 7a) and from $\mathrm{CHCl}_{3}$ (boat conformation/structure $7 \mathbf{a}^{\prime}$ ). Hydrogen atoms, solvent molecules (7a: $\left.2 \mathrm{DMF}, \mathbf{7 a}^{\prime}: 10 \mathrm{CHCl}_{3}\right)$ and a second molecular unit (7a') are omitted for clarity. Displacement ellipsoids are drawn at $30 \%$ probability level.

and the $\sigma-N$ coordinated nitroso ligand. The $\mathrm{M}-\mathrm{X}$ bond lengths found in $7 \mathbf{a}-\mathbf{c}$ and $\mathbf{8 a}$ are almost identical to those observed for the terminal halogenido ligands in the starting complexes 5a $(2.387(4) \AA),{ }^{65}$ 5b $(2.519(5) \AA),{ }^{66}$ 5c $(2.694(1) \AA)^{66}$ and $\mathbf{6 a}$ $(2.397(2) \AA)^{67}$ The angles enclosed by those or one halogenido ligand and the nitroso-N only differ by a few degrees from $90^{\circ}$ and so prove the slightly distorted geometry (Table 2 ). The distance between the $\eta^{5}-\mathrm{Cp}$-ring and the corresponding metal center is increased in 7a-c and $\mathbf{8 a}$ compared to $\mathbf{5 a}-\mathbf{c}$ and $\mathbf{6 a}$ due to dimer cleavage and nitroso coordination (5a: 1.7563(4) $\AA),{ }^{65}$ 5b: $1.771(2) \AA{ }^{66}$ 5c: $1.8013(3) \AA^{66}$ and 6a: $1.7558(3) \AA{ }^{\circ}{ }^{67}$ A list of plane to plane distances and angles within $7 \mathbf{a}-\mathbf{c}$ and $\mathbf{8 a}$ is available as ESI (Table 5). $\uparrow$ The $\mathrm{Ir}-\mathrm{N}$ bonds found in $\mathbf{7 a -}$ c range from 2.061(7) to 2.088(8) $\AA$ and are a little longer than those recently reported for a comparable Ir(III) complex (1.948(6) $\AA^{68}$ ) in which 1-chloro-2-nitroso-1,2-dihydrodicyclopentadiene is $\sigma-N$ coordinated. Crystallographic data for $\mathrm{Rh}(\mathrm{III})$ with $\sigma-N$ coordination of a $C$-nitroso ligand are not available. The only almost similar structurally characterized compound contains a $\mathrm{Rh}(\mathrm{I})$ center and 1-bromo-4-nitrosobenzene as a ligand with a $\mathrm{Rh}-$ $\mathrm{N}(\mathrm{O})$ bond length of $1.968(8) \AA^{69}$ which is somewhat shorter than that found in $\mathbf{8 a}$. Thus, the $\mathrm{M}-\mathrm{N}$ bond lengths observed in $7 \mathbf{a}-\mathbf{c}$ and $\mathbf{8} \mathbf{a}$ are in the range of $\mathrm{Rh}$ (III) and Ir(III) complexes, respectively, with bidentate $\mathrm{sp}^{2}-N$-donor ligands. ${ }^{70-74}$ The structural changes in 4 induced by the coordination process are by far not as strong as assumed. The $\mathrm{N}=\mathrm{O}$ bond length is only marginally effected. But few trends can be found in our crystallographic data (Table 2). N1-C7 and N1-C8 are slightly longer in 7a-c and 8a compared to 4. The sum of the angles of the piperzine- $\mathrm{N}$, already around $360^{\circ}$ in 4 for boat but $353.8^{\circ}$ for chair conformation, rises to values from 359.1 to $360.0^{\circ}$ regardless which conformation is found in $7 \mathbf{a}-\mathbf{c}$ and $\mathbf{8 a}$. This indicates a stronger quinoid contribution in the aromatic ring after coordination. The NO group is located in all complexes within the phenyl plane with only small deviations.

\section{Experimental}

\section{Materials and methods}

All experiments for the preparation of the complexes 7a-c and $\mathbf{8 a}$ were carried out under a dry argon atmosphere using Schlenk and vacuum-line techniques. The starting complexes $\left[\left(\eta^{5}-\mathrm{C}_{5} \mathrm{Me}_{5}\right) \operatorname{Ir} \mathrm{X}_{2}\right]_{2}$ $\left(\mathrm{X}=\mathrm{Cl}(\mathbf{5 a}),{ }^{75} \mathrm{Br}(\mathbf{5 b}),{ }^{76} \mathrm{I}(\mathbf{5 c})^{77}\right)$ and $\left[\left(\eta^{5}-\mathrm{C}_{5} \mathrm{Me}_{5}\right) \mathrm{RhCl}_{2}\right]_{2}(\mathbf{6 a})^{77}$ were prepared according to literature procedures. The published synthesis of the hydrochloride of BNPP (4) ${ }^{14}$ had to be modified to yield the pure compound. Solvents were purified by standard procedures; dichloromethane was distilled from calcium hydride and $n$-pentane from lithium aluminum hydride. Acetone and chloroform were dried dynamically in a column with a $3 \AA$ molecular sieve. All dried solvents were stored under a dry argon atmosphere with a $3 \AA$ molecular sieve (dichloromethane, chloroform) or sodium pieces (acetone, $n$-pentane), respectively. DMF (reagent grade) was purchased from VWR and used without further purification.

NMR spectra in solution were recorded with a JEOL Eclipse 400 spectrometer at ambient temperature unless stated otherwise. Solid-state NMR measurements were carried out at room temperature with a Bruker DSX Avance 500 FT spectrometer equipped with a commercial $2.5 \mathrm{~mm}$ MAS NMR double-resonance probe (samples contained in a $4 \mathrm{~mm} \mathrm{ZrO}_{2}$ rotor) at a magnitude field of $11.7 \mathrm{~T}$; the rotation frequency was $9 \mathrm{kHz}$. All chemical shifts were determined in parts per million relative to TMS. IR spectra $(\mathrm{KBr})$ were recorded using a Perkin Elmer Spectrum One FT-IR spectrometer in the range of $4000-400 \mathrm{~cm}^{-1}$. Mass spectra were obtained with a JEOL MStation JMS-700. Elemental analyses were performed by the Microanalytical Laboratory of the Department of Chemistry and Biochemistry using a Heareus elementar varioEL. Single crystal X-ray diffraction data were collected using a Nonius Kappa CCD and an Oxford Diffraction Xcalibur S with Sapphire CCD detector, both using graphite-monochromatized Mo-K $\alpha$ radiation. Structures were solved by direct methods 
with the SHELXS software and refined on $F^{2}$ by full-matrix least-squares with SHELXL-97. ${ }^{78}$ The PLATON ${ }^{79} /$ SQUEEZE $^{80}$ software was applied to subtract the contribution of heavily disordered solvent from diffraction data if no reasonable modeling was possible during refinement. SQUEEZE details are appended to the deposited final refinement CIF. CCDC numbers in Table 3 contain the supplementary crystallographic data for this paper. $\dagger$

\section{Synthesis of 1,4-bis(4-nitrosophenyl)piperazine (BNPP) (4)}

The modified synthesis of $\mathbf{4}$ is based on a literature method. ${ }^{14}$ The crude precursor 1,4-diphenylpiperazine (3) is obtained from aniline (1) and 1,2-dibromethane (2) by condensation where they (no solvent) are stirred with sodium carbonate (to quench generated $\mathrm{HBr}$ ) at $130{ }^{\circ} \mathrm{C}$ for $5 \mathrm{~h}$. For analytically pure 3 column chromatography (silica gel, dichloromethane $/ n$-pentane) is necessary. Colorless crystals of $\mathbf{3}$ suitable for X-ray analysis are obtained by isothermic diffusion of $n$-pentane into a solution of $\mathbf{3}$ in acetone.

For nitrosation $0.654 \mathrm{~g}(2.74 \mathrm{mmol})$ crude 3 was powdered and suspended in $20 \mathrm{ml}$ conc. $\mathrm{HCl}$ at $0{ }^{\circ} \mathrm{C}$. Then, a solution of $0.757 \mathrm{~g}(10.98 \mathrm{mmol}) \mathrm{NaNO}_{2}$ in $5 \mathrm{ml}$ distilled water was added slowly through a cannula to the bottom of the flask. The mixture turned brown immediately and was stirred at $0{ }^{\circ} \mathrm{C}$ for $10 \mathrm{~min}$. The resulting precipitate (1,4-bis(4-nitrosophenyl)piperazine (4) $\times 2 \mathrm{HCl})$ was filtered off, washed with cold diluted hydrochloric acid $(\mathrm{HCl}$ : water $=1: 1)$ and cold acetone. Then the crude hydrochloride of $\mathbf{4}$ was dried in vacuo and stored in argon. Yield $\mathbf{4}$ $\times 2 \mathrm{HCl}: 0.853 \mathrm{~g}(2.31 \mathrm{mmol}, 84 \%)$.

To remove $\mathrm{HCl}$ the hydrochloride of $\mathbf{4}$ was dissolved in methanol and triethylamine was added till the solution changed its color from red to light green. Then the mixture was absorbed onto $25.0 \mathrm{~g}$ ISOLUTE $^{\circledR}$ (Biotage) and dried in vacuo. Loading on ISOLUTE ${ }^{\circledR}$ is comparable to loading on silica, but it offers very sharp bands and does not affect the following chromatographical process. The pure green product $\mathbf{4}$ was isolated after column chromatography on silica gel (EtOAc/ $n$-pentane) and dried in vacuo. Yield: 0.481 $\mathrm{g}(1.62 \mathrm{mmol}, 59 \%)$. Green crystals (rods) were obtained by slow isothermic diffusion of $n$-pentane into a solution of $\mathbf{4}$ in acetone. Anal. Calc. for $\mathrm{C}_{16} \mathrm{H}_{16} \mathrm{~N}_{4} \mathrm{O}_{2}\left(296.324 \mathrm{~g} \mathrm{~mol}^{-1}\right)$ : C, 64.85; H, 5.44; N, 18.91. Found: C, 64.46; H, 5.50; N, $18.41 \%$. IR: $v_{\max } / \mathrm{cm}^{-1}$ (KBr) 3093w, 3055w, 2908w, 2872w, 2853w, 1597vs, 1557w, 1515vs, $1467 \mathrm{w}, 1446 \mathrm{~m}, 1373 \mathrm{~s}, 1358 \mathrm{vs} v(\mathrm{~N}=\mathrm{O}), 1325 \mathrm{vs}, 1398 \mathrm{~s}, 1283 \mathrm{~s}$, $1242 \mathrm{~s}, 1210 \mathrm{vs}, 1142 \mathrm{vs}, 1113 \mathrm{vs}, 1024 \mathrm{~s}, 941 \mathrm{~m}, 831 \mathrm{~m}, 824 \mathrm{~m}, 797 \mathrm{w}$, $718 \mathrm{~m}, 644 \mathrm{~m}, 516 \mathrm{w}, 503 \mathrm{w} .{ }^{1} \mathrm{H}$ NMR $\left(400 \mathrm{MHz},\left(\mathrm{CD}_{3}\right)_{2} \mathrm{SO}\right): \delta=$ $3.87\left(\mathrm{~s}, 8 \mathrm{H}, \mathrm{H}_{7}+\mathrm{H}_{8}\right), 7.03\left(\mathrm{~d},{ }^{3} J_{\mathrm{H}, \mathrm{H}}=8.8 \mathrm{~Hz}, 4 \mathrm{H}, \mathrm{H}_{2}+\mathrm{H}_{6}\right), 7.77(\mathrm{br}$ s, $4 \mathrm{H}, \mathrm{H}_{3}+\mathrm{H}_{5}$ ). ${ }^{1} \mathrm{H}$ NMR $\left(400 \mathrm{MHz}, \mathrm{CD}_{2} \mathrm{Cl}_{2},-60{ }^{\circ} \mathrm{C}\right.$ ): $\delta=3.87$ (s, $\left.8 \mathrm{H}, \mathrm{H}_{7}+\mathrm{H}_{8}\right), 6.61\left(\mathrm{dd},{ }^{3} J_{\mathrm{H}, \mathrm{H}}=9.4 \mathrm{~Hz},{ }^{4} J_{\mathrm{H}, \mathrm{H}}=2.0 \mathrm{~Hz}, 2 \mathrm{H}, \mathrm{H}_{2}\right.$ or $\left.\mathrm{H}_{6}\right), 6.65\left(\mathrm{dd},{ }^{3} J_{\mathrm{H}, \mathrm{H}}=9.4 \mathrm{~Hz},{ }^{4} J_{\mathrm{H}, \mathrm{H}}=1.9 \mathrm{~Hz}, 2 \mathrm{H}, \mathrm{H}_{2}\right.$ or $\left.\mathrm{H}_{6}\right), 6.94$ $\left(\mathrm{dd},{ }^{3} J_{\mathrm{H}, \mathrm{H}}=9.0 \mathrm{~Hz},{ }^{4} J_{\mathrm{H}, \mathrm{H}}=1.9 \mathrm{~Hz}, 2 \mathrm{H}, \mathrm{H}_{3}\right.$ or $\left.\mathrm{H}_{5}\right), 9.00\left(\mathrm{dd},{ }^{3} J_{\mathrm{H}, \mathrm{H}}\right.$ $=8.9 \mathrm{~Hz},{ }^{4} J_{\mathrm{H}, \mathrm{H}}=1.7 \mathrm{~Hz}, 2 \mathrm{H}, \mathrm{H}_{3}$ or $\left.\mathrm{H}_{5}\right) \cdot{ }^{13} \mathrm{C}$ NMR $(100 \mathrm{MHz}$, $\left.\left(\mathrm{CD}_{3}\right)_{2} \mathrm{SO}\right): \delta=44.8\left(\mathrm{C}_{7}+\mathrm{C}_{8}\right), 111.1\left(\mathrm{C}_{2}+\mathrm{C}_{6}\right), 154.6\left(\mathrm{C}_{1}\right), 163.0$ $\left(\mathrm{C}_{4}\right) \neq{ }^{13} \mathrm{C}$ NMR $\left(100 \mathrm{MHz}, \mathrm{CD}_{2} \mathrm{Cl}_{2},-60{ }^{\circ} \mathrm{C}\right): \delta=43.9\left(\mathrm{C}_{7}+\mathrm{C}_{8}\right)$, $109.1+109.4+110.0\left(\mathrm{C}_{2}+\mathrm{C}_{5}+\mathrm{C}_{6}\right), 141.1\left(\mathrm{C}_{3}\right), 153.7\left(\mathrm{C}_{1}\right), 162.3$ $\left(\mathrm{C}_{4}\right) .{ }^{13} \mathrm{C}$ NMR (solid state): $\delta=38.6\left(\mathrm{CH}_{2}\right), 43.9\left(\mathrm{CH}_{2}\right), 45.0$ $\left(\mathrm{CH}_{2}\right), 46.3\left(\mathrm{CH}_{2}\right), 110.0(\mathrm{CH}), 110.1(\mathrm{CH}), 112.2(\mathrm{CH}), 112.7$

\$ The signal of $\mathrm{C}_{3} / \mathrm{C}_{5}$ is missing in solution at room temperature due to rotation of the NO-group.
$(\mathrm{CH}), 142.5(\mathrm{CH}), 154.6\left(\mathrm{C}_{1}\right), 162.2\left(\mathrm{C}_{4}\right), 162.8\left(\mathrm{C}_{4}\right)$. MS (DEI): $m / z 296.2(100 \%)\left[\mathrm{M}^{+}\right], 148.2(8)\left[\frac{1}{2} \mathrm{M}^{+}\right], 134.2(24)\left[\frac{1}{2} \mathrm{M}^{+}-\mathrm{CH}_{2}\right]$, $120.2(10)\left[\frac{1}{2} \mathrm{M}^{+}-2 \mathrm{CH}_{2}\right]$.

\section{Synthesis of the complexes 7a-c and 8a: general procedure}

A saturated solution of BNPP (4) in dry dichloromethane (4$6 \mathrm{ml})$ was added slowly to a saturated solution of the starting complexes $\left[\left(\eta^{5}-\mathrm{C}_{5} \mathrm{Me}_{5}\right) \mathrm{IrX}_{2}\right]_{2}[\mathrm{X}=\mathrm{Cl}(\mathbf{5 a}), \mathrm{Br}(\mathbf{5 b}), \mathrm{I}(\mathbf{5 c})]$ or $\left[\left(\eta^{5}-\mathrm{C}_{5} \mathrm{Me}_{5}\right) \mathrm{RhCl}_{2}\right]_{2}(\mathbf{6 a})$ in dry dichloromethane (4-11 ml) and stirred at room temperature. The color of the combined solution instantly turned red. After the reaction was completed (see below) dichloromethane was evaporated to a volume of about $5 \mathrm{ml}$. Then $10 \mathrm{ml}$ of dry $n$-pentane were added and the products precipitated as green $(\mathbf{7 a - c})$ or brown $(\mathbf{8 a})$ solids. After filtration (schlenk fritt) the complexes were washed carefully with $2 \mathrm{ml}$ dry dichloromethane (cold), three times with $5 \mathrm{ml}$ dry $n$-pentane and dried in vacuo.

$\left[\mu_{2}-\left(1,4-B i s(4-n i t r o s o p h e n y l) p i p e r a z i n-N, N^{\prime}\right)\right.$ bis(dichlorido- $\left(\eta^{5}-\right.$ pentamethyl-cyclopentadienyl)-iridium(III))] (7a). Reagents: 86.0 $\mathrm{mg}(0.108 \mathrm{mmol})$ 5a, $32.0 \mathrm{mg}(0.108 \mathrm{mmol})$ 4. Reaction time: $72 \mathrm{~h}$. Yield: $63.7 \mathrm{mg}(0.058 \mathrm{mmol}, 54 \%)$, dark green powder. Crystals were obtained by slow isothermic diffusion of $n$-pentane into a nearly saturated solution of 7a in DMF (structure 7a, red platelets) or chloroform (structure $\mathbf{7} \mathbf{a}^{\prime}$, violet rods). Anal. Calc. for $\mathrm{C}_{36} \mathrm{H}_{46} \mathrm{Cl}_{4} \mathrm{Ir}_{2} \mathrm{~N}_{4} \mathrm{O}_{2}\left(1093.022 \mathrm{~g} \mathrm{~mol}^{-1}\right)$ : C, 39.56; H, 4.24; N, 5.13. Found: C, 39.30; H, 4.43; N, 4.87\%. IR: $v_{\max } / \mathrm{cm}^{-1}(\mathrm{KBr}) 3095 \mathrm{w}$, 3044w, 2963w, 2914w, 2866w, 1591vs, 1543w, $1517 \mathrm{~m}, 1450 \mathrm{~m}$, $1411 \mathrm{~m}, 1351 \mathrm{~m} v(\mathrm{~N}=\mathrm{O}), 1327 \mathrm{~s}, 1308 \mathrm{~s}, 1223 \mathrm{~s}, 1126 \mathrm{vs}, 1023 \mathrm{~s}$, $989 \mathrm{~m}, 940 \mathrm{~m}, 874 \mathrm{~m}, 835 \mathrm{w}, 723 \mathrm{~m}, 646 \mathrm{w}, 624 \mathrm{w}, 590 \mathrm{w} .{ }^{13} \mathrm{C}$ NMR (solid state): $\delta=8.9\left(\mathrm{CH}_{3}-\mathrm{C}_{5} \mathrm{Me}_{5}\right), 45.2+48.1\left(\mathrm{C}_{7}+\mathrm{C}_{8}\right), 88.6\left(\mathrm{C}_{\mathrm{q}}-\right.$ $\left.\mathrm{C}_{5} \mathrm{Me}_{5}\right), 111.0+113.0+122.7\left(\mathrm{C}_{2}+\mathrm{C}_{5}+\mathrm{C}_{6}\right), 140.5\left(\mathrm{C}_{3}\right), 153.9\left(\mathrm{C}_{1}\right)$, 155.6 $\left(\mathrm{C}_{1}\right), 165.4\left(\mathrm{C}_{4}\right), 167.2\left(\mathrm{C}_{4}\right)$. MS $\left(\mathrm{FAB}^{+}\right): \mathrm{m} / z 1093.1(<1 \%)$ $\left[\mathrm{M}^{+}+\mathrm{H}\right], 1057.1(<1)\left[\mathrm{M}^{+}-\mathrm{Cl}\right], 1022.2(<1)\left[\mathrm{M}^{+}-2 \mathrm{Cl}\right], 694.1(2)$ $\left[\mathrm{M}^{+}-\mathrm{IrCp}^{*} \mathrm{Cl}_{2}\right], 659.3(18)\left[\mathrm{M}^{+}-\mathrm{IrCp}^{*} \mathrm{Cl}_{2}-\mathrm{Cl}\right], 643.2(5)\left[\mathrm{M}^{+}\right.$ $\left.-\mathrm{IrCp} * \mathrm{Cl}_{2}-\mathrm{Cl}-\mathrm{O}\right], 624.2$ (4) $\left[\mathrm{M}^{+}-\mathrm{IrCp}^{*} \mathrm{Cl}_{2}-2 \mathrm{Cl}\right], 363.2$ (100) $[\mathrm{IrCp} * \mathrm{Cl}]$.

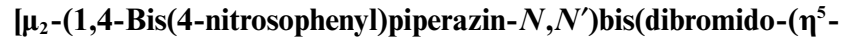
pentamethyl-cyclopentadienyl)-iridium(III))] (7b). Reagents: 98 $\mathrm{mg}(0.101 \mathrm{mmol})(\mathbf{5 b}), 29.9 \mathrm{mg}(0.101 \mathrm{mmol})(\mathbf{4})$. Reaction time: $93 \mathrm{~h}$. Yield: $116 \mathrm{mg}(0.091 \mathrm{mmol}, 90 \%)$, green powder. Red crystals (platelets) were obtained by slow isothermic diffusion of $n$-pentane into a nearly saturated solution of $\mathbf{7 b}$ in DMF. Anal. Calc. for $\mathrm{C}_{36} \mathrm{H}_{46} \mathrm{Br}_{4} \mathrm{Ir}_{2} \mathrm{~N}_{4} \mathrm{O}_{2}\left(1270.826 \mathrm{~g} \mathrm{~mol}^{-1}\right)$ : C, 34.02; H, 3.65; N, 4.41 . Found: C, 33.78; H, 3.77; N, 4.24\%. IR: $v_{\max } / \mathrm{cm}^{-1}(\mathrm{KBr}) 3086 \mathrm{w}$, 3041w, 2962w, 2910w, 2860w, 1593vs, 1541w, $1521 \mathrm{~m}, 1445 \mathrm{~m}$, $1410 \mathrm{~m}, 1367 \mathrm{~m}, 1349 \mathrm{~m} v(\mathrm{~N}=\mathrm{O}), 1327 \mathrm{~s}, 1303 \mathrm{~s}, 1249 \mathrm{~m}, 1222 \mathrm{~m}$, 1136vs, $1126 \mathrm{vs}, 1025 \mathrm{~s}, 988 \mathrm{~m}, 943 \mathrm{w}, 872 \mathrm{~m}, 820 \mathrm{w}, 724 \mathrm{~m}, 643 \mathrm{w}$, 622w, 590w. ${ }^{13} \mathrm{C}$ NMR (solid state): $\delta=9.7\left(\mathrm{CH}_{3}-\mathrm{C}_{5} \mathrm{Me}_{5}\right), 44.8$ $+46.3+46.5\left(\mathrm{C}_{7}+\mathrm{C}_{8}\right), 88.8+89.3\left(\mathrm{C}_{\mathrm{q}}-\mathrm{C}_{5} \mathrm{Me}_{5}\right), 110.5+110.8$ $+112.3+120.4+121.0\left(\mathrm{C}_{2}+\mathrm{C}_{5}+\mathrm{C}_{6}\right), 137.4+140.6\left(\mathrm{C}_{3}\right), 154.8$ $\left(\mathrm{C}_{1}\right), 154.8\left(\mathrm{C}_{1}\right), 156.8\left(\mathrm{C}_{1}\right), 164.9\left(\mathrm{C}_{4}\right), 165.0\left(\mathrm{C}_{4}\right), 168.2\left(\mathrm{C}_{4}\right)$. MS $\left(\mathrm{FAB}^{+}\right): m / z 1273.2(<1 \%)\left[\mathrm{M}^{+}+\mathrm{H}\right], 1190.1(<1)\left[\mathrm{M}^{+}+\mathrm{H}-\mathrm{Br}\right]$, $1110.3(<1)\left[\mathrm{M}^{+}-2 \mathrm{Br}\right], 783.2(2)\left[\mathrm{M}^{+}-\mathrm{IrCp}^{*} \mathrm{Br}_{2}-\mathrm{H}\right], 703.3(11)$ [ $\left.\mathrm{M}^{+}-\mathrm{IrCp} * \mathrm{Br}_{2}-\mathrm{Br}\right], 488.1$ (6) [Ir +BNPP], 407.2 (100) [IrCp*Br].

$\left[\mu_{2}-(1,4-B i s(4-n i t r o s o p h e n y))\right.$ piperazin- $\left.N, N^{\prime}\right)$ bis $\left(\left(\eta^{5}\right.\right.$-pentamethyl-cyclopentadienyl)-diiodido-iridium(III))] (7c). Reagents: 118 $\mathrm{mg}(0.102 \mathrm{mmol})(\mathbf{5 c}), 30.2 \mathrm{mg}(0.102 \mathrm{mmol})(\mathbf{4})$. Reaction time: $26 \mathrm{~h}$. Yield: $107 \mathrm{mg}(0.073 \mathrm{mmol}, 72 \%)$, green powder. Black 
crystals (rods) were obtained by slow isothermic diffusion of $n$ pentane into a nearly saturated solution of $7 \mathbf{c}$ in dichloromethane. Anal. Calc. for $\mathrm{C}_{36} \mathrm{H}_{46} \mathrm{I}_{4} \mathrm{Ir}_{2} \mathrm{~N}_{4} \mathrm{O}_{2}\left(1458.828 \mathrm{~g} \mathrm{~mol}^{-1}\right)$ : C, 29.64; $\mathrm{H}$, 3.18; N, 3.84. Found: C, 29.28; H, 3.42; N, 3.75\%. IR: $v_{\max } / \mathrm{cm}^{-1}$ (KBr) 3084w, 2985w, 2960w, 2910w, 2870w, 1590vs, 1539w, 1518 $\mathrm{m}, 1452 \mathrm{w}, 1410 \mathrm{~m}, 1378 \mathrm{~m}, 1347 \mathrm{~m} v(\mathrm{~N}=\mathrm{O}), 1325 \mathrm{~m}, 1298 \mathrm{~s}$, $1244 \mathrm{~m}, 1217 \mathrm{~m}, 1127 \mathrm{vs}, 1022 \mathrm{~s}, 985 \mathrm{w}, 941 \mathrm{w}, 871 \mathrm{~m}, 824 \mathrm{w}, 722 \mathrm{~m}$, $640 \mathrm{w}, 621 \mathrm{w}, 591 \mathrm{w} .{ }^{13} \mathrm{C}$ NMR (solid state): $\delta=12.5\left(\mathrm{CH}_{3}-\mathrm{C}_{5} \mathrm{Me}_{5}\right)$, $45.5\left(\mathrm{C}_{7}+\mathrm{C}_{8}\right), 90.3\left(\mathrm{C}_{\mathrm{q}}-\mathrm{C}_{5} \mathrm{Me}_{5}\right), 111.3+123.8\left(\mathrm{C}_{2}+\mathrm{C}_{5}+\mathrm{C}_{6}\right), 140.8$ $\left(\mathrm{C}_{3}\right), 155.2\left(\mathrm{C}_{1}\right), 166.2\left(\mathrm{C}_{4}\right)$. MS $\left(\mathrm{FAB}^{+}\right): m / z 1459.0(<1 \%)\left[\mathrm{M}^{+}\right.$ $+\mathrm{H}], 1331.2(<1)\left[\mathrm{M}^{+}-\mathrm{I}\right], 1204.2(<1)\left[\mathrm{M}^{+}-2 \mathrm{I}\right], 877.2(<1)$ $\left[\mathrm{M}^{+}-\mathrm{IrCp}^{*} \mathrm{I}_{2}+\mathrm{H}\right], 751.3(14)\left[\mathrm{M}^{+}-\mathrm{IrCp}^{*} \mathrm{I}_{2}-\mathrm{I}\right], 735.3(<1)\left[\mathrm{M}^{+}\right.$ $\left.-\mathrm{IrCp}^{*} \mathrm{I}_{2}-\mathrm{I}-\mathrm{O}\right], 623.4(<1)\left[\mathrm{M}^{+}-\mathrm{IrCp}^{*} \mathrm{I}_{2}-2 \mathrm{I}-\mathrm{H}\right], 455.2(100)$ [IrCp*I].

\footnotetext{
$\left[\mu_{2}-\left(1,4-B i s(4-n i t r o s o p h e n y l)\right.\right.$ piperazin- $\left.N, N^{\prime}\right)$ bis(dichlorido- $\left(\eta^{5}-\right.$ pentamethyl-cyclopentadienyl)-rhodium(III))] (8a). Reagents: $81.6 \mathrm{mg}(0.132 \mathrm{mmol})(\mathbf{6 a}), 39.1 \mathrm{mg}(0.132 \mathrm{mmol})$ (4). Reaction time: 74 h. Yield: $109 \mathrm{mg}(0.119 \mathrm{mmol}, 90 \%)$, brown powder. Red crystals (platelets) were obtained by slow isothermic diffusion of $n$-pentane into a nearly saturated solution of $\mathbf{8 a}$ in DMF. Anal. Calc. for $\mathrm{C}_{36} \mathrm{H}_{46} \mathrm{Cl}_{4} \mathrm{~N}_{4} \mathrm{O}_{2} \mathrm{Rh}_{2}\left(914.399 \mathrm{~g} \mathrm{~mol}^{-1}\right)$ : C, 47.29; $\mathrm{H}, 5.07$; $\mathrm{N}, 6.13$. Found: C, 46.78; H, 5.10; N, 5.87\%. IR: $v_{\max } / \mathrm{cm}^{-1}(\mathrm{KBr})$ 3056w, 2987w, 2963w, 2916w, 2868w, 1597vs, 1535 m, 1521 s, 1442 $\mathrm{m}, 1414 \mathrm{~m}, 1368 \mathrm{~m}, 1349 \mathrm{~s} v(\mathrm{~N}=\mathrm{O}), 1327 \mathrm{vs}, 1304 \mathrm{vs}, 1284 \mathrm{~s}, 1262$ s, $1215 \mathrm{vs}, 1149 \mathrm{vs}, 1116 \mathrm{vs}, 1026 \mathrm{~s}, 986 \mathrm{~m}, 942 \mathrm{~m}, 821 \mathrm{~m}, 718 \mathrm{~m}, 645$ m, 619 w, 559w. ${ }^{13} \mathrm{C}$ NMR (solid state): $\delta=10.4\left(\mathrm{CH}_{3}-\mathrm{C}_{5} \mathrm{Me}_{5}\right)$, $43.5+44.6+48.0\left(\mathrm{C}_{7}+\mathrm{C}_{8}\right), 94.3+98.8\left(\mathrm{C}_{\mathrm{q}}-\mathrm{C}_{5} \mathrm{Me}_{5}\right), 107.9+110.4$ $+114.8+122.6\left(\mathrm{C}_{2}+\mathrm{C}_{5}+\mathrm{C}_{6}\right), 137.6\left(\mathrm{C}_{3}\right), 139.3\left(\mathrm{C}_{3}\right), 153.5\left(\mathrm{C}_{1}\right)$, $156.4\left(\mathrm{C}_{1}\right), 162.3\left(\mathrm{C}_{4}\right), 163.0\left(\mathrm{C}_{4}\right)$. MS $\left(\mathrm{FAB}^{+}\right): \mathrm{m} / z$ 842.4 $(<1 \%)$ $\left[\mathrm{M}^{+}-2 \mathrm{Cl}\right], 807.3(<1)\left[\mathrm{M}^{+}-3 \mathrm{Cl}\right], 673.1(10)\left[\mathrm{M}^{+}-\mathrm{Cp}^{*}-3 \mathrm{Cl}\right]$, $637.1(1)\left[\mathrm{M}^{+}-\mathrm{Cp}^{*}-4 \mathrm{Cl}\right], 604.1(1)\left[\mathrm{M}^{+}-\mathrm{RhCp}^{*} \mathrm{Cl}_{2}\right], 273.2(100)$ $[\mathrm{RhCp} * \mathrm{Cl}]$.
}

\section{Conclusion}

In the present paper the synthesis, characterization and crystal structures of four complexes (7a-c, 8a) containing 1,4-bis(4nitrosophenyl)piperazine (4) as bridging ligand are reported. These are the first structurally characterized complexes of BNPP reported. Additionally X-ray analyses were also carried out of $\mathbf{4}$ and its precursor 1,4-diphenylpiperazine (3). There is only one earlier paper that claims the coordination of $\mathbf{4}$ to a metal center, but in contrast to our results via only one nitroso group. ${ }^{25}$ In view of the convenient synthesis of pure BNPP reported here and the crystallographic proof of stable complexes with BNPP coordinated on both sides, completely new fields of applications for example in metal organic frameworks arise. First experiments carried out with simple metallic salts already show promising results and will be published soon.

\section{Acknowledgements}

Financial support by the Ludwig-Maximilians University Munich and the Dr Klaus Römer Foundation is gratefully acknowledged.

\section{Notes and references}

1 V. Meyer and J. Locher, Ber. Dtsch. Chem. Ges., 1874, 7, 670-675. 2 V. Meyer and J. Locher, Ber. Dtsch. Chem. Ges., 1874, 7, 1506-1510.
3 A. Baeyer and H. Caro, Ber. Dtsch. Chem. Ges., 1874, 7, 809-811. 4 A. Baeyer and H. Caro, Ber. Dtsch. Chem. Ges., 1874, 7, 963-968. 5 A. Baeyer, Ber. Dtsch. Chem. Ges., 1874, 7, 1638-1640.

6 B. G. Gowenlock and G. B. Richter-Addo, Chem. Rev., 2004, 104, $3315-3340$.

7 B. G. Gowenlock and G. B. Richter-Addo, Chem. Soc. Rev., 2005, 34, 797-809.

8 M. Cameron, B. G. Gowenlock and G. Vasapollo, Chem. Soc. Rev, 1990, 19, 355-379.

9 J. Lee, L. Chen, A. H. West and G. B. Richter-Addo, Chem. Rev., 2002, 102, 1019-1066.

10 D. M. Gooden, H. Chakrapani and E. J. Toone, Curr. Top. Med. Chem., 2005, 5, 687-705.

11 W. Adam and O. Krebs, Chem. Rev., 2003, 103, 4131-4146.

12 B. G. Gowenlock and G. B. Richter-Addo, J. Chem. Educ., 2008, 85, $1243-1245$.

13 H. F. Morley, Ber. Dtsch. Chem. Ges., 1879, 12, 1793-1796.

14 D. S. Pratt and C. O. Young, J. Am. Chem. Soc., 1918, 40, 1428-1431.

15 V. S. Burykina, O. K. Vlasova and I. P. Kudina, Vopr. Khim. Khim. Tekhnol., 1979, 54, 89-91.

16 Y. I. Savin, A. S. Singin, G. K. Korolev, T. S. Safonova, V. G. Kurasova and V. V. Kurasova, Khim.-Farm. Zh., 1976, 10, 49-53.

17 Y. I. Savin, A. S. Singin, G. K. Korolev, T. S. Safonova, V. G. Kurasova and V. V. Kurchatova, Pharm. Chem. J., 1976, 10, 1627-1631.

18 Y. I. Savin, A. S. Singin and G. K. Korolev, Khim.-Farm. Zh., 1977, 11, 26-30.

19 Y. I. Savin, A. S. Singin and G. K. Korolev, Pharm. Chem. J., 1977, 11, 22-25.

20 FR Pat., 1311908 19621214, 1962.

21 R. Fabre and G. Bertrand, Rev. Gen. Caoutchouc Plastiques, 1965, 42, 405-412.

22 E. V. Goncharov, G. A. Suboch and V. M. Goncha, Izv. Vyssh. Uchebn. Zaved., Khim. Khim. Tekhnol., 2005, 48, 146-148.

23 D. V. Ershov, Izv. Vyssh. Uchebn. Zaved., Khim. Khim. Tekhnol., 2008, 51, 81-83.

24 US Pat., 2545176 19510313, 1951.

25 M. Cameron, B. G. Gowenlock, R. V. Parish and G. Vasapollo, J. Organomet. Chem., 1994, 465, 161-166.

26 H. Brunner and S. Loskot, Angew. Chem., 1971, 83, 546-547.

27 H. Brunner and S. Loskot, Angew. Chem., Int. Ed. Engl., 1971, 10, $515-516$.

28 H. Brunner and S. Loskot, J. Organometal. Chem., 1973, 61, 401-414.

29 G. Evrard, R. Thomas, B. R. Davis and I. Bernal, J. Organomet. Chem., 1977, 124, 59-70.

30 P. N. Becker, M. A. White and R. G. Bergman, J. Am. Chem. Soc., 1980, 102, 5676-5677.

31 P. N. Becker and R. G. Bergman, Organometallics, 1983, 2, 787-796.

32 P. N. Becker and R. G. Bergman, J. Am. Chem. Soc., 1983, 105, 29852995.

33 K. A. Joergensen and R. Hoffmann, J. Am. Chem. Soc., 1986, 108, $1867-1876$.

34 J. Müller, G. Manzoni de Oliveira and I. Sonn, J. Organomet. Chem., 1988, 340, C15-C18.

35 J. M. Schomaker, W. C. Boyd, I. C. Stewart, F. D. Toste and R. G. Bergman, J. Am. Chem. Soc., 2008, 130, 3777-3779.

36 J. M. Schomaker, F. D. Toste and R. G. Bergman, Org. Lett., 2009, 11, 3698-3700.

37 W. C. Boyd, M. R. Crimmin, L. E. Rosebrugh, J. M. Schomaker, R. G. Bergman and F. D. Toste, J. Am. Chem. Soc., 2010, 132, 1636516367.

38 W.-H. Chiu, K.-K. Cheung and C.-M. Che, J. Chem. Soc., Chem. Commun., 1995, 441-442.

39 M. R. Crimmin, R. G. Bergman and F. D. Toste, Angew. Chem., Int. Ed., 2011, 50, 4484- 4487.

40 K. V. Luzyanin, P. V. Gushchin, A. J. L. Pombeiro, M. Haukka, V. I. Ovcharenko and V. Y. Kukushkin, Inorg. Chem., 2008, 47, 6919-6930.

41 E. Colacio, J. M. Dominguez-Vera, A. Escuer, R. Kivekaes and A. Romerosa, Inorg. Chem., 1994, 33, 3914-3924.

42 R. Kivekas, M. Klinga, E. Colacio, J. M. Dominguez-Vera and A. Romerosa, Acta Crystallogr., Sect. C: Cryst. Struct. Commun., 1995, 51, 1087-1089.

43 A. D. Shebaldova, G. K. Kornienko and M. L. Khidekel, Bull. Acad. Sci. USSR, Div. Chem. Sci. (Engl. Transl.), 1975, 24, 1553-1555.

44 R. G. Cawthorne, J. Charalambous, W. M. Shutie, F. B. Taylor and A. Betts, Inorg. Chim. Acta, 1979, 37, 245-248. 
45 J. Charalambous, C. W. Newnham, F. Brian Taylor, M. J. Whelehan, K. W. P. White and I. G. H. Wilson, Polyhedron, 1987, 6, 1033-1035.

46 R. M. Awadallah, A. E. Mohamed, M. A. El Maghraby and A. E. M. M. Ramadan, Transition Met. Chem., 1990, 15, 273-277.

47 M. S. Masoud, A. M. Hindawey, M. A. Mostafa and A. M. Ramadan, Spectrosc. Lett., 1997, 30, 1227-1247.

48 Y.-F. Han, W.-G. Jia, W.-B. Yu and G.-X. Jin, Chem. Soc. Rev., 2009, 38, 3419-3434.

49 Y.-F. Han, H. Li and G.-X. Jin, Chem. Commun., 2010, 46, 68796890.

50 J. L. Boyer, M. L. Kuhlman and T. B. Rauchfuss, Acc. Chem. Res., 2007, 40, 233-242.

51 K. Severin, Chem. Commun., 2006, 3859-3867.

52 S. Kay, Coord. Chem. Rev., 2003, 245, 3-10.

53 K. K. Klausmeyer, T. B. Rauchfuss and S. R. Wilson, Angew. Chem., Int. Ed., 1998, 37, 1694-1696.

54 S. M. Contakes, K. K. Klausmeyer, R. M. Milberg, S. R. Wilson and T. B. Rauchfuss, Organometallics, 1998, 17, 3633-3635.

55 Y.-F. Han, H. Li, L.-H. Weng and G.-X. Jin, Chem. Commun., 2010, 46, 3556-3558.

56 H. Li, Y.-F. Han and G.-X. Jin, J. Organomet. Chem., 2011, 696, $2129-$ 2134.

57 W.-B. Yu, Y.-F. Han, Y.-J. Lin and G.-X. Jin, Chem.-Eur. J., 2011, 17, $1863-1871$.

58 H. Li, Y.-F. Han and G.-X. Jin, Dalton Trans., 2011, 40, 4982-4993.

59 W.-B. Yu, Y.-F. Han, Y.-J. Lin and G.-X. Jin, Organometallics, 2011, 30, 3090-3095.

60 Y.-F. Han and G.-X. Jin, Chem.-Asian J., 2011, 6, 1348-1352.

61 B. G. Gowenlock, M. J. Maidment, K. G. Orrell, I. Prokes and J. R. Roberts, J. Chem. Soc., Perkin Trans. 2, 2001, 1904-1911.

62 B. G. Gowenlock, K. G. Orrell, V. Sik and G. Vasapollo, Polyhedron, 1998, 17, 3495-3500.
63 C. Rømming and H. J. Talberg, Acta Chem. Scand., 1973, 27, 22462248.

64 L. J. Farrugia, Ortep-3 for Windows, (1997).

65 M. R. Churchill and S. A. Julis, Inorg. Chem., 1977, 16, 1488-1494.

66 M. R. Churchill and S. A. Julis, Inorg. Chem., 1979, 18, 1215-1221.

67 M. R. Churchill, S. A. Julis and F. J. Rotella, Inorg. Chem., 1977, 16, $1137-1141$.

68 N. Escola, A. Llebaría, G. Leitus and F. Doctorovich, Organometallics, 2006, 25, 3799-3801.

69 G. Vasapollo, A. Sacco, C. F. Nobile, M. A. Pellinghelli and M. Lanfranchi, J. Organomet. Chem., 1988, 353, 119-123.

70 M.-T. Youinou and R. Ziessel, J. Organomet. Chem., 1989, 363, 197208.

71 D. M. Tellers and R. G. Bergman, Organometallics, 2001, 20, 48194832.

72 S. Greulich, A. Klein, A. Knodler and W. Kaim, Organometallics, 2002, 21, 765-769.

73 P. Govindaswamy, Y. A. Mozharivskyj and M. R. Kollipara, Polyhedron, 2005, 24, 1710-1716.

74 D. F. Kennedy, B. A. Messerle and M. K. Smith, Eur. J. Inorg. Chem., 2007, 80-89.

75 R. G. Ball, W. A. G. Graham, D. M. Heinekey, J. K. Hoyano, A. D. McMaster, B. M. Mattson and S. T. Michel, Inorg. Chem., 1990, 29, 2023-2025.

76 D. S. Gill and P. M. Maitlis, J. Organomet. Chem., 1975, 87, 359-364.

77 J. W. Kang, K. Moseley and P. M. Maitlis, J. Am. Chem. Soc., 1969, 91, 5970-5977.

78 G. M. Sheldrick, Acta Crystallogr., Sect. A: Found. Crystallogr., 2007, 64, 112-122.

79 A. L. Spek, J. Appl. Crystallogr., 2003, 36, 7-13.

80 P. van der Sluis and A. L. Spek, Acta Crystallogr., Sect. A: Found. Crystallogr., 1990, 46, 194-201. 